This is the accepted version of the following article: González Reyero, S.; Sánchez-Palencia, F.J.; López Sáez, A.; Pérez Díaz, S.; Ruiz Alonso, M.; Romero Perona, D.; Vallés Iriso, J.; Álvarez-Ayuso, E., 2019: "Agrarian landscapes in the Iberian Iron Age: Mountain communities, land use and production in the southeastern Iberian Peninsula", Geoarchaeology. An International journal. 34: 252-271. https://doi.org/10.1002/gea.21698, which has been published in final form at https://onlinelibrary.wiley.com/doi/abs/10.1002/gea.21698 This article may be used for non-commercial purposes in accordance with the Wiley Self-Archiving Policy [http://www.wileyauthors.com/self-archiving].

\title{
Agrarian landscapes in the Iberian Iron Age: Mountain communities and land use in southeastern Iberia
}

\author{
Susana González Reyero ${ }^{1 *}$ \\ F. Javier Sánchez-Palencia ${ }^{1}$ \\ José Antonio López Sáez ${ }^{1}$ \\ Sebastián Pérez Díaz ${ }^{1}$ \\ Mónica Ruiz Alonso ${ }^{1}$ \\ Damián Romero Perona ${ }^{1}$ \\ Javier Vallés Iriso ${ }^{2}$ \\ Esther Álvarez-Ayuso ${ }^{3}$
}

\section{ABSTRACT}

Agrarian landscapes are among the least understood features of first millennium B.C societies in the western Mediterranean. Studies of such landscapes in the context of the Iberian Iron Age have been based essentially on the archaeological record in places used for purposes other than farming, particularly settlements and areas reserved for burials and rituals, or on the identification of the possible use of fertilizers.

This paper discusses a multi-proxy analysis based on geoarchaeological and paleoenvironmental studies in a mountainous region in southeastern lberia. The findings confirmed the existence of farmland cultivated as early as the first millennium B.C. in the high Jutia Valley in the Spanish province of Albacete. These results suggest that coordinated analyses can be highly useful for identifying enduring agricultural practices, while contributing to a fuller understanding of western Mediterranean agrarian landscapes and their millenarian resilience, attributable to the co-evolution of human communities and the environment.

KEYWORDS: Agricultural landscapes, land use, Iron Age, Iberia, western Mediterranean

\footnotetext{
1 Instituto de Historia-Centro de Ciencias Humanas y Sociales, Consejo Superior de Investigaciones Científicas. C/ Albasanz 26-28, 28037, Madrid, Spain.

* Corresponding author; E-mail: susana.gonzalezreyero@cchs.csic.es

${ }^{2}$ C.A.I. de Arqueometría y Análisis Arqueológico, Universidad Complutense de Madrid. C/ Prof. Aranguren s/n, 28040 Madrid, Spain.

3 Instituto de Recursos Naturales y Agrobiología de Salamanca, Consejo Superior de Investigaciones Científicas, Salamanca, España. C/ Cordel de Merinas 40-52, 37008 Salamanca, Spain.
} 


\section{INTRODUCTION}

Although a considerable corpus of research has been published on first millennium B.C. Mediterranean landscapes, relatively few case studies involving the western rim of the Mediterranean Basin have been conducted. Between the sixth and first centuries B.C., Iberian populations occupied the south and east of their namesake Peninsula. They had evolved from small-scale Late Bronze Age communities into more complex societies in which contact (of varying intensity depending on the region) with other Mediterranean populations also played a substantial role. As a rule, the Iberian Iron Age (hereafter IIA) was characterized by complex organizational systems and a hierarchized social structure. Substantial regional variation has nonetheless been found in their economic, political and cultural structures, including non-linear centralization and urbanization, with interruptions and reversals (Ruiz \& Molinos, 1993).

IIA agricultural practices have been defined as a system of grain, pulse and fruit cultivars, along with extensive ovicaprine, bovine and Suidae husbandry (see, among others, Alonso, 1999; Pérez Jordà et al., 2000; Chapa \& Mayoral, 2007; Mata et al., 2009; Serrano, Portero, \& Cano, 2011; Grau, 2014; 2016). The heterogeneous agricultural practices detected were geared to output ranging from subsistence to surplus, the latter sometimes intended for trade and based, among others, on fruit orchard farming and wine production. Hulled barley and naked wheat were the staples of grain production, whereas in the IIA short-cycle cultivars such as millet spread all across the eastern and southern Iberia. Pulses seemed to have been farmed more sparsely, although the taxa introduced with Neolithization (broad beans, peas, lentils, grass peas, vetches and bitter vetches or ervils) were maintained and chick peas began to appear. The most prominent fruit cultivars were grapes, although olives, figs, pomegranates, apples/pears and almonds were also grown.

Another approach to defining IIA agricultural practice, implemented in Iberia in recent years, is to construe surface scatter of archaeological material as possible evidence of cultivated fields (Wilkinson, 1989; Mayoral et al., 2006; Grau, 2016). Similarly, pottery and the stratigraphic sequences observed in a number of excavations have firmly established a series of Iron Agerelated agricultural infrastructures or fields (Serrano, Portero, \& Cano, 2011; Serrano, 2015; Echevarría \& Vera, 2015; Sánchez, Bravo \& Madaria, 2015), although in other cases some authors have highlighted the difficulties in establishing precise chronologies (Rodríguez, 
Chautón \& Duque, 2006). As a rule, however, ${ }^{14} \mathrm{C}$-dated sequences are scarce up to Roman times (Sánchez-Palencia, 2014; Sánchez-Palencia, Romero \& Beltrán, 2012; 2014; SánchezPalencia et al., 2014; Puy \& Balbo, 2013), with the number rising from Medieval Muslim times when irrigated agriculture underwent significant development (Brown \& Walsh, 2017, 29).

Current research on IIA agricultural production can be characterized by a number of features. The first is the dependence of present knowledge on findings for certain regions where more studies have been conducted, such as what are now Valencia, Catalonia and Andalusia (Bonet, Mata \& Moreno, 2007; Buxó, 2008; Serrano, Portero \& Cano, 2011; Pérez Jordà, 2013). As research has been more intense on coastal and sedimentary basin areas, case studies of other kinds of landscapes are acquiring great interest. A second feature is the difficulty involved in furthering the understanding of the types of land ownership, contended to be communal although with access regulated by patronage arrangements and unequal ownership of means of production, controlled by the ruling groups (Ruiz et al., 2007, 239). A third significant characteristic of IIA research is the paucity of studies on the fields themselves where agriculture and livestock raising were conducted. In other words, research on agricultural practice has been based on material or organic remains directly or indirectly related to agricultural production but found elsewhere, primarily in dwellings or religious contexts. While that record may on occasion denote local production, it is also socially mediated, for it includes not only what the community grew but also everything stemming from practices such as trade. Its direct equivalence to local agricultural output is consequently problem-ridden. For that reason, an understanding of both records, cultivated fields and other documented contexts, is believed to be of great interest to better identify local agricultural production and trading practice. That entails researching the crop and livestock farming landscapes themselves, the places where farming or shepherding were conducted, to generate a record for comparing the organization and evolution of these productive areas as part of the socialization of the landscape. Furthermore, the present definition of Iron Age agricultural practice will surely benefit from the study of a variety of orographies and landscapes.

We consequently aim to understand long-term landscape dynamics and past and present land use in an Iberian inland mountain region. That entails establishing agricultural output and the organization and evolution of the landscape over time. The role of farming and livestock 
production in social change and hierarchization are also discussed, underscoring the importance of land as a counterweight to the traditional and at times excessive emphasis on the role of Mediterranean imports and prestige goods in the generation of inequality.

Moreover, focusing on uplands adds variety to the case studies on land use in the ancient western Mediterranean. Frequently, not to say consistently, mountain landscapes have been less intensely studied and are still burdened with certain acritical perspectives and stereotypes of assumed marginality not in keeping with recent research findings attesting to their early anthropization (Ejarque \& Orengo 2009; López-Sáez et al., 2014). The mountain areas of the peninsula's southeast, a region deemed as a key to Iron Age social dynamics, have been nonetheless absent from recent studies on upland communities. The potential particularity of western Mediterranean mountains is in need of research, along with its constantly changing relationship with the surrounding plains, to characterize the inter-connection between these different ecosystems over time.

\section{STUDY AREA}

The Segura River, the backbone of southeastern Iberia, connects the Mediterranean coast to the inland mountains (Figure 1). From its source, the upper river runs across a landscape forming part of the Baetic Mountains, one of the Iberian Peninsula's major morpho-structural units, consisting in a series of NE-SW-oriented, more or less parallel ranges, with peaks of up to 2000 masl delimiting deep valleys. The landscape features a wide variety of morphologies, with compartmentalized, rugged reliefs and a broad range of altitudes from mountain summits to valley floors. It is also a major hydrographic node with hosts of springs feeding the main rivers in an area characterized by highly irregular yearly and seasonal rainfall. Its great spatial complexity and highly variable response to climate change have also been established (Carrión, 2002, 2064). With a temperate Mediterranean climate, the region has a mean yearly rainfall of $600 \mathrm{~mm}-700 \mathrm{~mm}$ and mean yearly temperatures ranging from $9{ }^{\circ} \mathrm{C}$ to $14^{\circ} \mathrm{C}$.

Jutia, an upland valley (1280 masl-1550 masl) that hugs the upper course of the Segura River, is defined by wide, internal Pre-Baetic folds and normal faults that in the valley strike predominantly N30-50E (Figure 1). Photointerpretation and field work provided the data to characterize its most prominent geomorphological features (Figure 2). The valley lies on limestone delimited by minor elevations (Torca del Agujero, Morro de los Calderones), forming a 
basin with an area of approximately 3220 ha. Its various seasonal and permanent springs (such as Fuente del Álamo and Fuente de Jutia) are characteristic of a Mediterranean hydrological regime. Its two main stream beds, the Rambla de Comina and the Arroyo de Rivelte, empty into the Zumeta River, a typical example of calcareous Mediterranean mountain rivers on the western end of the valley, defined by steep ravines, depressions and watercourses resulting from the river's confined course and tendency to meander.

The hillside materials consist essentially in limestone, dolostone, sandstone and conglomerate subject to the karstic weathering that prevails in the region. This study focused on two predominantly flat or gently sloping areas of the valley floor (Figure 3) apt for high capacity farming on scantly developed soils (MCA, Yetas de Abajo 1982, 11). Springs such as Jutia and El Álamo are vital to the farms in the area, where Lower Cretaceous to Quaternary outcrops comprise primarily colluvial and eluvial deposits (Fort et al., 2017). These narrow, discontinuous flood plains are marked by the presence of sandy marls and alluvial deposits in the form of sand and loam (Figure 2).

The holm-oak typical of supra-Mediterranean bioclimatic soils that prevails on the hillsides is found along with gall-oak, savin and juniper. The most severely deforested areas, abandoned after agricultural or silvicultural use, have been invaded by low brush such as rosemary, gum cistus, thyme, lavender, English lavender and sage. A few scattered farms on some of the bioclastic limestone outcrops on the valley floor defined traditional human settlement. Always near sources of water, these farms practiced traditional agriculture, with dry crops, pastures and small irrigated vegetable gardens for self use and alfalfa, as well, on occasion, as small terraced fields. Ovine and caprine, followed by porcine and, to a much lesser degree, bovine livestock was raised. The abandonment of this type of settlements in the nineteen sixties led to near depopulation of the valley, with the attendant gradual ruination of its buildings and an increase in erosion. Like other Mediterranean landscapes, Jutia forms part of an area where the cultural heritage is quickly vanishing (Brown \& Walsh, 2015, 32).

Multi-disciplinary, multi-scale work has been ongoing since 2009 to explore the occupation and use of the upper Segura River basin during the IIA. At Jutia the pattern consisted predominantly of small-to-medium settlements (Cerro de Jutia, Jutia-El Álamo), ranging from $5000 \mathrm{~m}^{2}$ to 2 ha. The existence of a ritual and monumental area dated to the fourth century B.C. onwards attests 
to occupancy in the IIA. Possible traces of productive activity were explored to gain insight into land use and farming practice. This article discusses the methods and results, while assessing the findings against a broader perspective of past and present land use in these Mediterranean uplands.

\section{MATERIALS AND METHODS}

The study was designed from a comprehensive, multi-scale, multi-intensity and inter-disciplinary perspective. Priority was accorded to non-destructive methods such as photo-interpretation, geophysics and surveys to characterize the valley morphologically, detect anomalies and make high-resolution maps of the areas of interest. Several sectors were defined accordingly. The ones referred to here are sectors 4 and 5 (Figure 3). A combination of geospatial, archaeological and paleo-environmental multi-proxy techniques were applied to study the spatial structure of the valley's archaeological record.

\section{1- Photo interpretation and remote sensing}

Photo-interpretation of historic aerial photography made by the USAF and the Army Map Service (AMS 1946 and AMS 1956-57, footnote 1), provided archaeo-morphological data, with an initial diagnosis of the archaeological potential of several areas. Stereoscopic analysis revealed a series of anomalies in the 1956 photography that suggested the existence of terraces in part of the valley (Sector 5). Based on aerial data and field survey evidence, the research strategy consisted in an appraisal of traditional land use over time. Stereoscopic analysis of the 1946 and 1956 aerial photography and photogrammetric geo-referencing allowed for the creation of a vector layer that could be combined with raster layers such as a DEM or the respective ortho-photograph. Such ortho- and geo-referencing was performed by bundle block photogrammetric triangulation based on highly precise control points.

Interpretation of the historical aerial photography was used to determine the agrarian potential of the valley based on strictly traditional farming techniques. In Jutia, traditional practice means the non-mechanized practice in use until recently. The farms characteristic of traditional valley settlements had neither running water nor electricity. They formed part of a socio-economic context that limited the use of agricultural machinery until very recently (late nineteen nineties) when mechanization came in the wake of ownership concentration, which altered prior lot fragmentation and a number of the agricultural features revealed by photo-interpretation. 
The historic aerial photography revealed areas of maximum potential interest, appraised as the differences between calculated potential and actual land use maps (Figure 4). Farmed and unfarmed (scrub-covered) areas were distinguished and rock outcrops were marked based on National Aerial Ortho-photographic Plan (PNOA) ortho-photos. The National Geographic Information Center's (CNIG) 25 m DEM was used to develop a percentage slope model for Jutia Valley land. Its re-classification into four ranges $(0-10 \%, 10-20 \%, 20-30 \%$ and $>30 \%)$ was based on land potential studies such as the Productive Capacity of Galician Soils (CPSG, DíazFerros \& Gil, 1984) and the FAO's GAEZ Programme (http://www.fao.org/nr/gaez/programme/en/).

\section{2- Archaeological survey}

Geospatial technology-aided selective, intensive and geophysical surveys of different areas of the valley were conducted to confirm the photo-interpretation and remote sensing findings and analyze land use through history.

An off-site survey model (Foley, 1981), which records the distribution of material culture beyond the local site paradigm, assuming land use to be a continuous whole (Bintliff, 2000; Bintliff \& Snodgrass, 1988a; Tartaron et al., 2006), was prioritized. As prior information on the valley was virtually nil, selective and intensive surveying based on the specific characteristics of each area of the valley (visibility, slopes) was required to maximize the potential for documenting anthropic activity. A Garmin eTrex 3 hand-held GPS was used to establish the overall areas of material scatter, together with a Leica 1200 bi-frequency GPS and a Leica TCRP1203+ total station laser theodolite for intensive study. The maps were made by creating a series of reference points for GPS stationing and the total station, corrected with Tocón geodesic grid vertex No. 90393. ArcGis 10 software was used to process the information, including high resolution orthophotographs (0.25 m/pixel), 1:25 000 vegetation maps, 1:25 000 geomorphological maps, and a $25 \mathrm{~m} /$ cell digital terrain model of the area studied. All archaeological items were mapped either with CNIG (www.cnig.es) data or other WMS servers (www.ign.es; www.chsegura.es). All the material cultural items, their features and surrounding topography were typed chronologically and digitized in a GIS-based geodatabase for subsequent analysis and conversion into continuous areas to determine spatial patterns.

\section{3-. Geophysical survey}


Ground penetrating radar (GPR)-mediated geophysical surveys were conducted in sectors 4 and 5 to identify structures possibly related to farming. Area lithology is characterized by grey and red clay soils with quartzite and sandstone gravel and scattered limestone or dolostone boulders. High data resolution was obtained with Ingenieria del Sistemi (IDS) $200 \mathrm{MHz}$ and $600 \mathrm{MHz}$ multichannel antennas fitted with 15 and 12 dipoles spaced at $12 \mathrm{~cm}$ and $8 \mathrm{~cm}$, respectively.

Rather than applying georadar in areas with a concentrated archaeological record on the surface, the strategy deployed prioritized the study of areas with a convergence of factors that initially suggested recurrent farming. These were located around areas with anthropic activity during the first millennium B.C.. Photo-interpretation identified farmed terraces (in Sector 5), now razed, and a series of cairns (in Sector 4), also now razed, which other case studies associated with livestock raising or farming improvements (Hammer, 2014, 281). In Spanish cadastral records, this parcel of land is known as "loma de los majanos" ("cairn hill").

Taken together, these factors served to identify sectors 4 and 5 as areas with characteristics that supported their recurrent use for traditional farming prior to today's artificial irrigation and mechanization. On those grounds, they were chosen for more detailed review. The georadar identified Sector 5 (Figure 4) as more significant. A 260 m longitudinal section was scanned with the $200 \mathrm{MHz}$ antenna to an estimated depth of around $3 \mathrm{~m}$, with variations depending on the moisture attenuation in the clays. The purpose was to locate possible structural remains, given the apparent dismantling of terraces observed in the aerial photographs. In addition, an area of Sector 4 was chosen for more intense exploration to differentiate farming horizons and possible agricultural features. A total of 29 transects were performed in 319 georadar sections covering an area of $300 \mathrm{~m}^{2}$.

\section{4- Archaeological sequences and paleo-environmental studies}

Five archaeological trenches were also conducted in sectors 4 and 5 to confirm the preliminary assessment based on non-invasive methods, characterize soil composition, obtain stratigraphic sequences and collect paleo-environmental material in well-sealed strata only, an important condition for ancient crop field surveying (Carter \& Davidson, 1998, 545).

Excavation was conducted to standard stratigraphic unit (SU) and soil horizon (SH) identification procedures (Courty, Goldberg \& Macphail, 1989, 7-10). The sedimentary 
sequence was studied in four stratigraphic trenches, two of which (T2 in Sector 5 and T6 in Sector 4, Figures 5 and 6 ) are discussed in depth here. In addition to the standard recording of stratigraphic units (SUs) and materials, the methodology involved sampling sediments in welldefined archaeological contexts and their subsequent processing in a flotation machine fitted with a $1 \mathrm{~mm}$ inner and a $0.25 \mathrm{~mm}$ outer mesh grid to gather botanical remains. After drying, both fractions were viewed under a low-power stereoscopic microscope for selection.

Four pollen samples each were taken from Sector 5, trench T2 and Sector 4, trench T6 (Figures 7 and 8). The profiles were sampled from bottom up, carefully so as not to mix macroscopically visible layers or structures. An average of $10 \mathrm{~g}$ of sediment was chemically treated to remove mineral fractions. The method described by Burjachs et al. (2003) was deployed to extract pollen and non-pollen palynomorphs (NPP), which were concentrated with Thoulet's liquor (Goeury \& de Beaulieu, 1979). A total of 250 grains, excluding NPPs and anthropogenic taxa such as Cichorioideae and Cardueae (López-Sáez et al., 2003), were extracted from the residue, previously suspended in glycerin, for examination under an optical microscope at a magnification of $400 x$ or $1000 x$. Pollen types were identified using pollen keys (Moore et al., 1991), pollen atlases (Reille, 1999), and the reference collection at the CSIC Archaeobiology Laboratory in Madrid, Spain. The cerealia type, measuring over $45 \mu \mathrm{m}$ with an annulus diameter of at least $8 \mu \mathrm{m}-10 \mu \mathrm{m}$, was assigned to the Poaceae family (Beug, 2004; López-Sáez \& López-Merino, 2005). Vicia faba pollen was palynologically discriminated based on criteria published by Hidalgo \& Fernández (1996). Most of the NPPs on the pollen slides could be identified; van Geel's (2001) nomenclature was used. Pollen diagrams were drawn with TGVies software (Grimm, 2004).

Thirteen anthracological and five carpological samples were recovered by flotation and manual gathering and analyzed in the aforementioned archaeo-biological laboratory. Cross- and radial longitudinal and tangential longitudinal sections of $>2 \mathrm{~mm}$ wood remains were viewed under a Leica DM 400M (50x/100x/200x/500x) incident light microscope, whereas carpological remains were studied under a binocular microscope at several magnifications. Charcoal was identified by comparing the anatomical characteristics of the archaeological material to the laboratory's reference collection of modern timber and the Schweingruber (1990), Hather (2000) and Vernet 
et al. (2001) wood anatomy atlases. Seeds and fruits were identified with the aid of the same archaeo-biological laboratory's reference collection.

Samples for Radiocarbon $\left({ }^{14} \mathrm{C}\right)$ dating were collected from the top layer in each $\mathrm{SU}$ after inspecting the buried soil horizons and sampling areas that appeared to be uncontaminated by younger charcoal (no channels cutting across both terrace landfills or Ab horizons, no signs of mixing...). Samples were stored in dry conditions. Since no datable macrofossils were found in samples $2,5,6,9,13$ or 14 , the bulk organic fraction was dated after removing the carbonates. The remaining ${ }^{14} \mathrm{C}$ dates were determined from charred carpological and anthracological materials. AMS pre-treatment and ${ }^{14} \mathrm{C}$ dating were performed at the Beta Analytic Laboratory (Miami, U.S.) and the Upsala Laboratory (Sweden). The ${ }^{14} \mathrm{C}$ ages shown were calibrated to two-sigma ranges (Reimer et al., 2013) using Oxcal 4.2 (Bronk, 2009) and CALIB 5.0 software and the IntCal13 curve. Both the original radiocarbon dates and the 2- $\sigma$ calibration values are given in Table 2.

Physical and chemical analyses were conducted on (air-dried at $25^{\circ} \mathrm{C}$ ) bulk samples from the center of each soil horizon sieved through a $2 \mathrm{~mm}$ mesh to separate the coarse and fine fractions and determine the gravel content. The $<2 \mathrm{~mm}$ soil fraction was selected for subsequent physical-chemical characterization $(\mathrm{pH}$, electrical conductivity $(\mathrm{EC})$ and carbonate, organic matter (OM), nitrogen, available phosphorus, potassium, calcium and magnesium content, and texture). Soil $\mathrm{pH}$ was determined with the water-saturated paste method and EC analyses were conducted on 1:5 soil/water extracts. Soil O.M. was found with the Walkley-Black dichromate oxidation procedure. Carbonate content was measured volumetrically as per ISO standard 10693 (1995) with a Bernard calcimeter. Nitrogen content was determined by quantifying ammonia (as proposed by Kjeldahl) on a Bran Luebbe AA3 continuous segmented flow autoanalyzer to the procedure described in ISO 11732 (2005). The available P was extracted with the Olsen sodium bicarbonate method and quantified spectrophotometrically (molybdenum blue) with $\mathrm{SnCl}_{2}$ as the reducing agent. The available $\mathrm{K}, \mathrm{Ca}$ and $\mathrm{Mg}$ were extracted with ammonium acetate and analyzed for atomic emission/absorption on a Varian Spectra AA-220 spectrometer. Soil texture was determined by pipetting.

\section{RESULTS}

\subsection{Non-invasive methods}


Photo-interpretation of the valley identified potential land use by cross-referencing maximum farming with the slope potential and assigning potential use categories $(A, B, C$ or $D)$, for which surface areas and percentages were defined. Two IIA settlements (Cerro de Jutia and Jutia-EI Álamo) were identified based on structures deduced from photo interpretation and material evidence mapped in archaeological surveys. An isochrone contour map with $15^{\prime}$ intervals for different types of soil was also drawn (Figure 4), taking the Jutia-El Álamo settlement as the center and using site catchment analysis (SCA)-based surface cost analysis (Vita-Finzi \& Higgs, 1970). The isochrone contour map was obtained by applying the Gorenflo and Gale (1990) formula: $\mathrm{V}=6$ e $-3.5|\mathrm{~s}+0.05|$

Assuming (dry and irrigation) farming, livestock raising and forestry as the three basic uses of Mediterranean agricultural landscapes (Gilman, 2013) and features revealed on the 1946 photography as representative of the basic potential and land use on a general scale, a few conclusions could be drawn despite obvious technical and economic change. The first finding was that in the areas inhabited in the IIA, a substantial amount of cultivated fields, particularly for dry farming, could be accessed within half an hour. These "A" dry farming areas might have potentially included small irrigable zones, depending on the proximity of seasonal water resources. The isochrone contour map also showed that an abundance and variety of other resources, especially forests and pastures, were accessible within 15-45 minutes.

Photo-interpretation likewise identified sectors 4 and 5 (Figure 3 ) as potentially apt for traditional farming. They were consequently chosen to conduct archaeological trenches on those grounds rather than other possible criteria, such as areas with a substantial scatter of material culture. While the parallel archaeological survey yielded more significant results in the first millennium B.C. settlements and the ritual area (Figures 5 and 7 ), very little was gleaned in the agricultural areas selected for study. Certain perspectives, such as the combined application of statistical test and geopedological analysis (Casarotto at al., 2017), could nuance these results by assessing the extent of possible biasing factors.

The longitudinal section in Sector 5 obtained by geophysical surveying revealed an alluvialcolluvial mantle over the ancient terraces (Figure 6). No evidence of sub-surface architecture was found, except in the second-most southern terrace. In the area most intensely studied, all the radargrams showed over $50 \mathrm{~cm}$ of topsoil and signals with a wide wave amplitude (greater 
signal amplitude denotes reflection of the energy transmitted to the subsoil and consequently the presence of materials with different dielectric coefficients). Below the topsoil, contact was continuous and while the boundary line was not sharp, it was horizontal. The layer below was more or less uniform with an occasional anomaly that might denote a boulder. Although these findings strongly suggested the existence of areas probably associated with the presence of gravel or moisture, they were not conclusive; confirmation would call for convergence with other data.

\subsection{Archaeological sequences and paleo-environmental studies}

Cambisols, regosols and to a lesser extent, lithosols, fluvisols, phaeozems and rendzins prevail in these inland Prebaetic soils. The association of calcium cambisols and calcareous regosols, which generally evolve in areas with gentle slopes such as studied here, account for the highest percentage (Alías, 1993, 28; Trueba et al., 1995; MMA, 2002; De la Cruz et al., 2010; Pérez et al., 2016, 1318) They are common over limestone, dolostone or marl, at the bottom of mountains or hills, in colluvia or closed basins. Regosols are scantly developed (AC or ABC profile), have an alkaline $\mathrm{pH}$ and high carbonate, $\mathrm{Ca}$ and $\mathrm{Mg}$ contents. Cambisols, which tend to accumulate calcium carbonate, have an $\mathrm{ABC}$ profile, an alkaline $\mathrm{pH}$ and a high nutrient and carbonate content. The slope and instability are not as a rule suited to the formation of a mollic epipedon and they have an ochric A horizon. They are characterized by a xeric and occasionally a ustic moisture regime (Albaladejo, 1991, 154) and subject to limitations associated with summer drought, erosion, a higher percentage of limestone in some areas and generally deficient drainage.

The trenches analyzed here were dug in an alluvial-colluvial area (with limestone, calcarenite and local calcarenite-sandstone bioclasts: Figure 2, sectors 4 and 5). Their cultivation through time favored the appearance of more or less complex sequences of cultivated soils (Ap, Figures 6 and 8 ) and cultivated and buried soils (Ab, Figure 8 ). They are clearly differentiated by their morphology and composition (with disturbance associated with plowing and the presence of medium and very small roots), at times by the presence of with ancient pottery (Table 1) and a high organic matter or nitrogen content. These anthropized (Ap or Ab) soils overlie nonstratified B soil horizons, which exhibit mineral alteration (SU 5, Trench 6), or AB transition soils (SU 4, Trench 2), where the values of organic matter are clearly lower (Table 3). 
The trenches exposed a fairly thick $(40 \mathrm{~cm}-60 \mathrm{~cm})$ topsoil $(\mathrm{SU} 1)$, SH Ap1, associated with moldboard plowing. The field descriptions for this and subsequent stratigraphic units (SUs) in the two sectors are given in Table 1.

The stratigraphic sequence documented in Sector 5, trench 2 (Figure 8) consisted in a second $\mathrm{SH}, \mathrm{Ap}_{2}$ (SU 2), immediately preceding the present sequence, with brown (7.5YR 4/3), loose, medium sandy clay and some gravel. Charred material from this SU was dated to $810-540$ cal. B.C. and a bulk organic fraction to $255-405$ A.D. (Table 2). The third SH differentiated, Ap3 (SU 3), featured an accumulation of limestone, medium-sized sandstone and quartzite gravel and brown (7.5YR 5/3), sandy clay. Coarse material accounted for $69.3 \%$ of the total. Eight oxidized pottery fragments were found in this unit, including sherds from an Iberian or Roman Republican jar (group I, type 2, Mata \& Bonet, 1993, 125). Evidence of small snails was also found, associated in other cases with farming, pedological change or strong bioturbation (Carter \& Davidson, 1998, 535; Puy, Balbo \& Bubenzer, 2016). Two Triticum durum/aestivum samples and material from the bulk organic fraction were dated respectively to 420-520 A.D., 250-439 A.D. and $200-45$ B.C..

The fourth SH, AB (SU 4), consisted of a brown (7.5YR 5/3) sandy clay loam, devoid of stones at the top but darker brown (7.5YR 5/3-5/6) with gravel and boulders near the bottom. It included small, worn, scantly diagnostic ceramic sherds. Its transition to the natural SH, C (SU 5), was very gradual. A bulk organic fraction dated to 805-770 B.C. and charred material dated to $770-410$ B.C. were obtained from SU 4. The short number of carpological samples from this trench were all remains of cultivated grain, caryopses that when well conserved could be identified as naked wheat (Triticum aestivum-durum).

The pollen sequence from T2 (Figure 9) exhibited $36-54 \%$ of arboreal, primarily Pinus sylvestris/nigra, (24-36 \%) and deciduous Quercus (3-13\%) pollen, with Juniperus and Fraxinus consistently present. The large percentage of Pinus sylvestris/nigra was attributed to long-range ("regional") transport of pollen from highland areas (López-Sáez et al., 2013). Of the abundant shrubbery $(9-15 \%)$, the predominant taxa were Cytisus/Genista, Ephedra fragilis, Pistacia lentiscus and Rhamnus. At 13-30\%, Poaceae was the primary herbaceous component. Large percentages of anthropogenic nitrophilous (mainly Aster, Cardueae, Cichorioideae and Malva sylvestris) as well as anthropozoogenic nitrophilous (Chenopodiaceae, Urtica dioica) herbs 
were also present. Cerealia accounted for considerable percentages: $5.3 \%$ in SU 2 and Vicia faba for 2.0-3.6\% in SU 4, although the record was discontinuous. Hygrophytic taxa (Cyperaceae, HdV-182) and Glomus each accounted for $<8 \%$, except in SU2, where the latter amounted to $128 \%$ of the pollen sum.

This sequence contrasted sharply with the findings for nearby trench 1 (Figure 8), where a second $\mathrm{SH}, \mathrm{Ap}_{2}$ (Figure 8), with brown gray (7.5YR 5/2-5/1), sandy clay, with relatively high organic content was documented immediately beneath the topsoil. It rested on a B SH (SU 3), a colluvial and mostly horizontal deposit, comprising stone and a brown-gray (7.5YR 5/2-6/1) sandy clay. SU 4 was observed to be a buried horizon (SH AB) with brown-dark gray (7.5YR5/2-4/1) organic matter-bearing sandy clay.

Consisting essentially of forest taxa, the carpological samples in this trench varied from the findings documented in T2. In T1, SU 2, the two taxa documented were a Rubiaceae (Asperula arvensis), which can grow in wasteland and as a weed in farmland, and one of the most common IIA weeds, a Poaceae (Lolium perenne-rigidum) (Alonso Martínez, 1999). That dissimilarities were observed in both the stratigraphic sequence and the carpological remains in T1 and T2 reinforced the distinction between these two areas of Sector 5.

Excavations in Sector 4 revealed a different soil-stratigraphic sequence. Situated beneath the modern plow zone (Ap1; SU1), the Ap2 (SU 2) horizon contained a brown-grayish brown (10YR 5/3-5/2) clay loam with relatively high organic matter content (Figure 10, Table 1). It might have been soil cultivated immediately prior to the present topsoil. The very recent ${ }^{14} \mathrm{C}$ date obtained from a wheat caryopsis may denote traditional agriculture conducted from a nearby farm (Table 2).

Beneath the Ap2 was a buried A horizon subdivided into Ab1 and Ab2. The Ab1 horizon (SU3) was a gray (7.5YR 5/1) sandy clay with many loose pebbles and small, mostly non-diagnostic pottery fragments and small snails. These were interpreted as redeposited materials associated with the nearby burial-ritual area. A sample from the sediments was ${ }^{14} \mathrm{C}$ dated to $990-1145$ A.D.. The Ab2 horizon (SU 4), consisted of a very homogeneous, organic matter-high, dark gray (7.5YR 4/1) fine clay with evidence of small snails. A Triticum durum/aestivum sample ${ }^{14} \mathrm{C}$ dated 
to $390-200$ B.C. was attributed to IIA farming. A second ${ }^{14} \mathrm{C}$ dating to $540-395$ B.C. corroborated that chronology. Moreover, the percentage of $\mathrm{N}$ in SU 4 was higher than in the preceding SUs (SU 5 and 6), a finding consistent with the effect of $N$ on cereal output (Arnold, 1988). The texture of SU 4, the sole clay in the T6 sequence, was optimal for growing wheat in the presence of abundant Ca, as in this case (López Bellido, 2009). SU 5 and 6 (SH B and C) were archaeologically sterile. The former was mixed gray (7.5YR 5/1) sandy clay with $65.1 \%$ gravel, very likely associated with alluvial deposition, and the latter a very compact yellowish brown (10YR 5/4) sandy clay originating from fragmented natural rock.

In the T6 pollen record, Pinus sylvestris/nigra and Poaceae exhibited percentages (Figure 11) similar to the values for Sector 5, T2, the maximum for pine (31\%) being consistent with the minimum (12\%) for grasses in SU 5. The Juniperus, deciduous Quercus and Fraxinus pollen percentages were similar in Sector 4, T6 and Sector 5, T2, whilst evergreen Quercus values (5$9 \%$ ) were higher in the former. Cerealia was also documented, at $8 \%$ in SU 4 and $2 \%$ in SU 2. The presence of most shrubs (Ephedra fragilis, Cytisus/Genista, Rhamnus, Pistacia lentiscus) and herbs (Liliaceae, Fabaceae, Scrophulariaceae, Geranium) was significant and continuous. Nearly all the samples contained anthropogenic nitrophilous herbs (Aster, Cardueae, Cichorioideae, Malva sylvestris), although the highest values for these and anthropozoogenic nitrophilous herbs (Urtica dioica) and Glomus were recorded in SU 4 and SU 2. Cyperaceae (9\%) was present only in the basal SU 5 sample.

Trench 7 appeared to corroborate the data on farming over an extended period of time (Figure 10). When ${ }^{14} \mathrm{C}$ dated with Pinus sp., the second SH, Ap 2 (SU 2) (a brown (7.5YR 5/3), sandy clay with numerous stone, boulder and pottery fragments), exhibited a recent chronology (Table 2). It lay over a third buried $\mathrm{SH}, \mathrm{Ab} 1$ (SU 3), comprising a brown-gray (7.5YR 5/2-5/1) sandy, compact, homogeneous clay levelled to a natural layer (detected in the geophysical survey) with barely any stone or pebbles but a fair amount of pottery fragments. The bulk organic fraction was ${ }^{14} \mathrm{C}$ dated twice, to 45 B.C. to A.D. 75 and 60 to 180 A.D., suggesting possible continuous farming in this area from the Iron Age.

The $\mathrm{pH}$ of the soils in the sectors studied ranged from 8.0 to 8.3 (Table 3), an alkalinity consistent with their classification as highly or very highly calcareous in terms of their $\mathrm{CaCO}_{3}$ equivalent content (15.6-34.9\%) (Day, 1983). Their texture was either heavy (sandy clay and 
clay) or medium (sandy clay loam and clay loam). Their EC values $\left(\leq 0.20 \mathrm{dS} \mathrm{m}^{-1}\right)$ lay within the non-saline range $\left(0-0.35 \mathrm{dS} \mathrm{m}^{-1}\right)$. Their O.M. content fluctuated fairly widely, from $<1.5-2.6 \%$. They exhibited low $(0.062-0.151 \%)$ or normal $(<0.10 \%) \mathrm{N}$ content levels. Both O.M. and $\mathrm{N}$ levels decrease with depth. The calcareous nature of these soils limited the concentration of their available $\mathrm{P}$ (2.0-5.0 mg kg-1). That notwithstanding, phosphorous enrichment relative to other strata in the same sequence must be borne in mind when inferring anthropic activity (Mujika-Alustiza et al., 2013, 231). Under such conditions, phosphate reacts with Ca to form scantly soluble compounds (Mortvedt, Murphy \& Follet, 1999; Zhang et al., 2014). At $93.1 \mathrm{mg} \mathrm{kg}^{-1}$ to $192 \mathrm{mg} \mathrm{kg}^{-1}$, the available $\mathrm{K}$ in soils was regarded as low ( $<160 \mathrm{mg} \mathrm{kg}^{-1}$ ) or medium, whereas, typically in calcareous soils, available $M g\left(105 \mathrm{mg} \mathrm{kg}^{-1}-178 \mathrm{mg} \mathrm{kg}^{-1}\right)$ was medium-high and $\mathrm{Ca}\left(>9000 \mathrm{mg} \mathrm{kg}^{-1}\right)$ very high.

On the grounds of both the morphological and the analytical data, the soils were classified as forming part of the calcareous cambisols prevalent in the area (Alías, 1993; Pérez et al., 2016, 1318), which generally constitute good farmland and are presently in intensive use. Nonetheless, on steep slopes, cambisols are better conserved under forests (WRB, 2007).

The anthracological findings were scanty in terms of both the number of samples examined and the number of fragments they contained (Supplementary Table 1). Remains could not be identified in six of the samples due to the small size of the fragments $(<2 \mathrm{~mm})$, which was consistent with reports on other cultivated fields (Puy, Balbo \& Bubenzer, 2016). The rest of the samples contained Quercus ilex/coccifera $(n=5)$, Pinus sp. $(n=3)$, deciduous Quercus $(n=2)$ and yew $(n=2)$ wood fragments, as well as one possible Juniperus fragment. A few $(n=7)$ other fragments of wood found could not be identified due to the vitrification of their anatomic structures.

In addition to these samples from sectors 4 (T6) and 5 (T2), considerable effort was deployed to recover and study the valley in other contexts, such as the burial-ritual area referred to earlier. There Quercus ilex/coccifera was by far the wood most used, accounting for $91 \%$ of the total. Despite that prevalence, other taxa were also identified, including pine, deciduous Quercus species, pulses, Rosaceae, elements related to hydric needs, such as maple, elm, ash and an occasional yew fragment. Pine accounted for around $6 \%$ and the remaining taxa together just $2.2 \%$ of the total identified. 


\section{DISCUSSION}

\subsection{Chronology of sedimentary deposits}

${ }^{14} \mathrm{C}$ dating at the top of the buried soils is commonly used to obtain the chronology of farming infrastructure construction and the use of farmland, based on the assumption that the date delivered refers to the most recent sources of organic matter prior to soil coverage. As a number of authors have noted, however, that depends on a number of factors, such as the absence of: younger carbon infiltrating down from the sediment above, alteration of horizon $\mathrm{A}$ or carbon older than the sample to be dated (Gilet-Blein, Marien \& Evin, 1980; Holliday, 2004; Puy, Balbo \& Bubenzer, 2016). Soils are obviously open systems where organic matter accumulates over time (Puy \& Balbo, 2013, 54). Therefore, excavating farmland entails acknowledging the existence of mixed soils and the movement of dated artefacts or ecofacts in the soil (Boissinot, 2000, 38).

The inference is that numerical ages on soil organic matter should be interpreted with care and are more likely to have a higher degree of accuracy when samples come from undisturbed contexts, e.g., high concentrations or lenses of charcoal (Rendu et al. 2015, 473). In addition to using multiple dating methods, contextualizing the findings in archaeological and sedimentary sequences renders them more useful (Frederick \& Krahtopoulou, 2008).

Here five measures were taken to address that issue. First, several chronologies were established in each SU, dating not only separate organic items (wood, seeds), but also the bulk organic fraction to contrast and assess the possible prior or subsequent ingress of organic matter. Second, the samples were taken from the top layer, a precaution particularly necessary in terraced areas due to the use of frequently heterogeneous landfill. Third, each SU was always contextualized within its archaeological sequence and with possibly associated artefacts. Fourth, physical-chemical data were analyzed to determine the degree of homo/heterogeneity and therefore of possible alteration or mixing, a strategy deployed in other studies (Puy, Balbo \& Bubenzer, 2016). The findings showed that the physical-chemical characteristics of topsoil SUs and SUs bearing evidence of ancient cultivars clearly differed. Fifth, another approach used to analyze dating consistency, namely the observation of possible chronostratigraphic inversions, was applied (Rendu et al., 2015, 473). In this case, samples 2 , $5,6,11,12,13$ (Table 2) exhibited a consistent sequence, without inversions. As a rule, IIA or 
Roman Republican dates were systematically observed in SUs overlying units with older dates, delivering sequences consistent both internally and with the stratigraphy and the remains of material culture. The sole exception was sequence SU 2-3 in Sector 5, discussed later.

As the numerical ages tended to cluster in two periods, IIA-Roman Republic and Late Antiquity, consequently identified as times of land use and development.

\subsection{Agrarian practices in the southeastern Iberia}

These findings support the hypothesis that two areas of the Jutia Valley have been farmed consistently, very likely from the Iron Age. Further to present knowledge, Jutia is one of the few case studies where AMS 14C dating, geoarchaeological and paleo-environmental data were integrated to analyze IIA agrarian landscapes, putting forward hypotheses and arguments for a subject area to be developed and studied in greater depth in future.

At this writing, evidence of grain and pulse farming has been found in SUs that could be dated to the first and second Iron Ages. In Sector 5 (T2, SU 4), Early Iron Age pulse farming (for broad beans at least) is hypothesized on the grounds of the pollen record (Figure 9) and soil organic matter and charred material dating (samples 6 and 7, Table 2), This crop, well known in the Iron Age (Buxó et al., 2010, 85), has been documented in nearby areas such as Amarejo, in the Spanish province of Albacete. Fabaceae species are known to be able to form symbiotic relationships with soil bacteria that fix atmospheric nitrogen in a form usable by plants, minimizing the external supply of the element needed. As Fabaceae are also a source of nitrogen for subsequent crops, they are often rotated with grains (Chalk, 1998). No evidence of such rotation was observed at Jutia, although the narrow scatter of the grain pollen must be borne in mind (López Sáez \& López Merino, 2005). Fabaceae species can also adapt to a wide range of soil $\mathrm{pH}$ conditions (from acidic to alkaline). Vicia faba can grow in soils with $\mathrm{pH}$ from 5.8 to 9.0, and optimally at 6.5-8.0 (Nadal, Moreno, \& Cubero, 2004). The pH in SU 4, where farming was identified, had a $\mathrm{pH}$ of 8.1 . As a rule, these plants prefer neutral, Ca-high soils, given their need for that nutrient. They adapt as well to different soil textures (from sandy to clayey), although Vicia faba L. prefers medium-textured soils (Singh et al., 2013). Further to the pollen data for Jutia, cultivation of these crops concurred with high human impact (high values for anthropogenic nitrophilous herbs) and intense deforestation during a particularly warm dry period, attested to by the presence of thermophilous species such as Pistacia lentiscus and 
Ephedra fragilis and the low occurrence of local arboreal species (oak forests). The record of anthropozoogenic nitrophilous herbs may suggest seasonal grazing.

The presence of cereal pollen and wheat grains, the latter dated to Late Antiquity, between the third and sixth centuries A.D. (SU 2-3, T2), was also documented, denoting a long historical agricultural series in the area, that is ongoing today.

In Sector 4, pollen analysis showed that grain, probably wheat based on the carpological remains identified, was grown in the IIA. The samples were dated to the Iberian (third to sixth centuries B.C.) and contemporary eras. In the Iberian era in SU 4, it appeared in conjunction with high values of Glomus and anthropogenic nitrophilous herbs (primarily Cardueae and Cichorioideae), associated with deforestation-mediated erosion (declining numbers of evergreen Quercus) and farming (Tallón-Armada et al., 2014, 35). Physical-chemical analysis also detected higher Ca rates in SU 4 than in the rest of the sequence, possibly denoting practices such as fertilization or liming (Ferro-Vázquez et al., 2014, 28). The Roman republican and imperial chronologies observed in T7 supported farming continuity in this area near the Jutia-El Álamo settlement.

These findings appear to indicate that naked wheat, a grain apt for an upland area such as the Jutia Valley, was the crop recurrently grown in different eras. Given the quality of the valley soil, such wheat may have been preferred as the most digestive and nutritious grain, unlike other Iberian regions with poorer soils where Hordeum vulgare vulgare was more prevalent (Buxó 1997, 279).

The record in another part of the valley, the Iberian ritual area referred to earlier (Figures 3 and 5), contained grain, primarily naked wheat and to a lesser extent hulled barley, pulses and fruit such as grapes, olives and almonds. As the source for that record may be either the valley and immediate surrounds or trade imports, it cannot be attributed with all certainty to valley production, particularly since these taxa were not identified in the pollen analyses. The altitude and frost season in Jutia, which may have altered the production of some types of fruit, would not have impacted grain or broad beans. If these archaeobotanical remains in the ritual area were local, the farming pattern would resemble those traditionally defined for a wide range of Mediterranean regions, with a landscape of mostly wheat and barley fields (Halstead, 1987, 78).

\subsection{Possible agricultural infrastructure in Jutia}


The present findings support the possibility of farming infrastructure. A unit bearing limestone gravel, sandstone, calcareous sandstone and brown (7.5YR 5/3) sandy clay was observed in SU 3 (T2, Sector 5). The characteristics of that SU would rule out its interpretation as either a geological stratum or a layer with remains of wall-like structures. Neither their clasts very uniform size, more or less rounded edges and random orientation, nor their internal structure are characteristic of deposition compatible or identifiable with geological deposits commonly found in similar contexts. Nor does they resemble the type, size or arrangement of stone in other ancient wall-like typologies in the region.

The combination of these factors, along with the presence in this SU of ancient pottery, supports the possible association of SU 3 with an ancient agricultural structure. Of the various possibilities, the hypothesis that would appear to afford the best fit to the available evidence is that SU 3 formed part of a drainage system. Given the limitations to the record presently available, however, this hypothesis must be contrasted by future research, as a deeper understanding of the agrarian spaces of these societies is progressively acquired.

That notwithstanding, in light of its significance, the idea merits some consideration. Drainage systems were described by a number of classical authors, including Columella (De re rustica), Varro (Rerum rusticarum libri III), Cato the Elder (De agricultura) and Palladius (Opus agriculturae) (White, 1970, 149). Drainage systems have been described archaeologically in Cinque Terre and in Hellenistic fields at Saint-Jean-du-Désert (Boissinot, 2001, 48). Such ancient examples have not been found in Iberia, although the technique appears to have been widespread in the Middle Ages (Rendu et al., 2015; Puy, Balbo \& Bubenzer, 2016).

The fossae caecae (closed ditches) described by Columella (De re rustica II, 2, 10) merit mention: ditches half-filled with small pebbles (lapides minuti) or clean gravel (nuda glarea), topped off with the excavation soil. The interpretation defended here is that SU 3 might have served a purpose similar to that of the Roman era pebbles in Columella's treatise.

As noted earlier, two naked wheat (Late Antiquity) as well as sediment and ceramic sherds (IIARoman Republican) were dated in SU 3, T2 (samples Nos. 3-5, Table 2). That suggests either a long and continuous time series or a number of discrete stages. The drainage system interpretation might explain the scant thickness of this layer and its periodic variety, for drainage would hinder sediment accumulation and running water would explain the presence of materials 
dating from widely different eras (Rendu et al., 2015). Other explanations are also possible, such as the possible percolation of more recent materials to SU 3 (Ap3). The drainage hypothesis, in turn, would also explain the higher percentage of hygrophytic plants such as Cyperaceae in the pollen sample (SU 3) and the steep decline in the percentages of anthropogenic nitrophilous herbs in this unit relative to the farmed soils in under- and overlying units SU 4 and SU 2. The consistency between the pottery fragments and republican Roman dating is believed to be significant, and the consistency in the Late Antiquity dating for the two wheat remains in SU 3 and the soil in SU 2, especially significant. In keeping with the dating for the soil and pottery fragments in SU 3 , the most plausible explanation is that it was formed between the dates attributed to SU 4 (805-770 B.C./770-410 B.C.) and the later Iberianrepublican Roman era when SU 3 was in use. It would have been buried around 255-405 A.D., the date for the SU 2 soil that followed, when cultivated grains (according to the pollen analysis) might have occasionally percolated downward, resulting in the Late Antiquity dating in SU 3.

Yet another argument supports that hypothesis. The presence of phosphorus, given its stability, is used in soil studies to assess human action (Sánchez \& Cañavate, 1998). At $5.0 \mathrm{mg} / \mathrm{kg}$, phosphorus concentration in SU 3 resembled the value for SU 4, where farming was also established, but was quite distinct from the $2.0 \mathrm{mg} / \mathrm{kg}$ found for the Late Antiquity-dated SU 2, rendering similarity of activity and possible mix with the latter unlikely (Table 2). All the foregoing suggests the existence of a long-lasting agricultural feature that was already in use beginning in the second to first centuries B.C. and may have lasted through 255-405 A.D.

The possible existence of a drainage system in Sector 5 is of interest insofar as it infers agricultural infrastructure and hence an investment in work and planning to raise output. The T2 evidence, however, deviates from the findings in lower elevation trenches T1 and T4, which exhibited natural sequences. The aforementioned variation in the physical-chemical characteristics and carpological remains between sequences T2 and T5 provides further support for the anthropic nature of the T2 sequence, in turn posing questions on the causes of such differences in the stratigraphic sequences. One plausible explanation is that the T2 area was separated in some way from T1 and T4. The valley floor must have had some manner of erosion-prevention structure that would explain these stratigraphic differences. As the T2 area has minimal slope, a small structure would have sufficed to retain moisture and prevent erosion. 
The inter-trench stratigraphic differences observed in Sector 5 consequently support the existence of land-conditioning structures on the valley floor.

This discussion is particularly relevant for, despite certain ancient Mediterranean examples (Butzer, 2005, 1795; Brown et al., 2017) and the importance of terracing in dry land agriculture in early complex societies, terraced field systems remain challenging targets for dating and interpretation (Fall et al., 2012, 2336). Case studies like the Jutia survey are therefore deemed useful to drive progress from the mere detection of agriculture to the study of more complex issues such as land management and use.

Moreover, terracing and drainage tend to go hand-in-hand, forming joint systems (Rendu et al., $2015 ; 467)$. The present hypothesis is that modern terracing, attested to in mid-twentieth century aerial photographs but no longer extant, may have buried structures on the oldest hillside, as has been theorized for other landscapes (Bal et al., 2010). If this drainage-terracing hypothesis is correct, it would provide a basis for premising possible transformation involving the creation of improved farmlands around the second century B.C. The small size of the area improved would infer its use for family- or small-scale gardens able to support small communities.

\subsection{Land use and social dynamics in a mountainous landscape}

At present no evidence supports the existence of practices such as crop rotation, long-term storage, manuring or other indicators of surplus production, although the non-existence of evidence is not necessarily evidence of non-existence. As noted, a dense pattern of scattered items has been suggested to be indicative of fertilization and evidence of cultivated fields. No such inference could be drawn here, for the findings suggest the existence of cultivated fields but no significant scatter of material culture on the surface. In sectors 4 and 5 both, the areas farmed exhibited a very low density of surface and buried materials. That paucity rules out their possible fertilization with ceramics. Although certain agricultural practices may be detectable on the grounds of the presence of a dense scatter of archaeological material on the surface, the present findings suggest that other practices, such as found at Jutia, may not conform to that type of detection, although the farming involved sufficed to support a community.

The aforementioned fertilization hypothesis is associated with periods when the environment was under population pressure, such as at Thespiae (Bintliff \& Snodgrass, 1988a), confirming 
Wilkinson's view that such massive fertilizing campaigns were a sign of high population or even ecological stress (Bintliff, 2011, 18). Lighter population pressure may have failed to induce such recognizable surface scatter. Nor should other possible forms of fertilization be ruled out, such as manure (Butzer, 2005, 1795) or the mixing of other nearby land (Nicosia et al., 2013), whilst variations in soil acidity, P and Ca contents might denote fertilization or liming (Ferro-Vázquez et al., 2014, 28).

This absence of elements related to agricultural specialization or intensification would nonetheless provisionally suggest a model involving extensive land use geared primarily to subsistence farming, which was not uncommon in many Mediterranean regions in the Iron Age. The characterization defended here, i.e., extensive and diversified farming and livestock raising, is consistent with the type of resource use generally attributed to uplands.

The Baetic systems are very appropriate for pasturing and human occupancy in the summer (Carrión et al,. 2001). These lands may have been grazed, for instance, for thousands of years prior to the last millennium, without showing any trace of that activity (López Sáez et al., 2009). Although knowledge of this region is scant, some of the data implies the existence of joint shepherding and farming. The research conducted in Jutia's ritual area documented the deposit of ovicaprine bones and the presence of parts of looms made with the same bones, all dated to the IIA. In addition, the wider region has yielded a substantial volume of weaving-related material culture, present for instance at the Archivel necropolis lying at $37 \mathrm{~km}$ and the Macalón settlement at $12 \mathrm{~km}$ from Jutia. The large number of roads (paths, cattle tracks) and structures (corrals, drinking troughs) conserved or plotted on ancient maps is indicative of the potential for and practice of livestock raising in the area. The pollen sequences found for both Jutia and Sabinar (Carrión et al., 2004) provide evidence of shepherding as a resource use since the first millennium B.C. Despite such indications, the scale and intensity of these practices in the IIA must be assessed with care, to avoid drawing an uncritical analogy between known traditional practice and the way of life of these ancient communities (Halstead, 1987, 77).

Although preliminarily, the present data suggests the existence of productive structures consistent with grain and pulse farming, livestock raising, trade and harvesting. The existence of farming questions the presumption that upland societies engaged nearly exclusively in shepherding, advocating rather for mixed and complementary farming and livestock raising. In 
this diversified production strategy, the primary aim of trade would be to obtain the resources absent in the community or to overcome periods of scarcity. Generally speaking, this is consistent with the characterization of Iberian agriculture as a household scale system, stable over time, able to adapt to different levels of political organization in periods of regional centralization and de-centralization (Grau, 2014, 132).

The priority accorded subsistence does not mean that these communities did not pay some manner of structural or circumstantial levy. Like other rural societies, they would have been involved in complex and changing relationships with a diversity of regions. Among others, such complex relationships would have brought certain products of prestige (in Jutia, weapons, imported pottery, bronze and silver rings or stone sculptures: Gener et al., 2016; Fort et al., 2017) as part of the various networks of personal interdependence in which these communities would be involved.

Nonetheless, the possible existence of drainage and terracing defended here would denote investment in work, adaptation and resilience to mountain conditions that may have improved or intensified production in the area adjacent to a settlement (Cerro de Jutia). The small size of the area is clearly indicative of the limited scope of the objectives and the community involved.

The Jutia case is, to date, consistent with and supports the association of uplands with extensive use, which is not incompatible with small-scale intensive use such as family gardens or the gradual introduction of iron plows. From that perspective, rough terrain and extensive land use would have prevailed in Jutia mountain communities, although given the abundance of water and the rich soil they may have had small irrigated areas and others that could be transformed for critical grazing in certain seasons.

\section{CONCLUSION}

This study identified fields in the Baetic Mountains that have been cultivated over centuries, perhaps since the Iron Age. It showed that data from high resolution research, both spatial (a number of multi-proxy sequences, aerial photo-interpretation and archaeological surveys and excavation) and chronological, can be meaningfully integrated, thereby supporting the suitability of combining methods to study agricultural land use.

The evidence found of farming from the first millennium B.C was used to hypothesize on the use of farmland between the sixth century B.C. and Late Antiquity. The data suggested the 
existence of three periods of agricultural land use (first millennium B.C., Late Antiquity and twentieth century). Possible upgrading and improvement of these lands for farming was also hypothesized, in which extensive general use would co-exist, possibly from Roman Republican times, with reconditioning. Farming in this upland valley would yield both goods for immediate consumption and surplus, providing for social differentiation strategies such as competitive feasting. Trade would have afforded access to a series of non-local products apt for use in redistribution, feasting and commensality. Although the archaeological record is fragile or even invisible, it shows that land was the mainstay of change and continuity in ancient Mediterranean agrarian societies.

This study constitutes a first step toward reconstruction of pre-industrial land use strategies in the Baetic Mountains. The chronologies and land use described diverge from preconceived ideas on uplands as areas un- or only sporadically inhabited in ancient times. This study in fact challenges the idea that mountain areas were by nature marginal, stressing their anthropization and connection with and integration into the surrounding regions. More than isolated geographies, uplands were major reservoirs of economic resources (Barker, 2005).

The hypothesis put forward is that their economy was diversified, based on both farming and livestock raising, thanks to which risks could be regulated and community survival was not at the mercy of either of the two strategies. That is consistent with the malleability and adaptability of Mediterranean uplands defended by Horden and Purcell's (2000) intensification and abatement model, while underscoring intense interaction with surrounding areas.

Research on mountain areas is likewise relevant today, for they are undergoing major transformation due to the decline in traditional activities. Research on how human and ecological resilience has maintained Mediterranean productivity across millennia must be undertaken before this rich record is irremediably lost. That entails regarding uplands and their possible specific forms of resilience as a long-range product of the ongoing interdependence between human labor and "nature".

\section{Acknowledgements}

This study forms part of projects HAR2012-35208 and HAR2015-67355-P funded by the Spanish Ministry of the Economy and Competitiveness and of heritage research programs funded by the Regional Government of Castile-La Mancha and the Central Government's Provincial Office of Albacete. The authors gratefully acknowledge the support provided by the History Institute's (CCHS, a Spanish National 
Research Council body) R\&D laboratories, the Archaeobiology Laboratory, and in particular L. Peña-

Chocarro and G. Pérez Jordà, for the carpological study and J.L. Pecharromán of the Landscape and Remote Sensing Laboratory (LABTEL) for the GIS study. Manuscript edited by M. Clark, professional translator and English language science editor. The reviewers and editors are thanked for their careful reading of and comments on the manuscript, from which the paper has benefited substantially.

\section{7- REFERENCES}

Albaladejo Montoro, J. (1991): Edafología. In P. López (ed.), El cambio cultural del IV al II milenios A.C. en la comarca Noroeste de Murcia, Madrid: CSIC.

Alías Pérez, L. J. (1993). Moratalla. Mapas de suelos. Madrid: ICONA.

Alonso, N. (1999). De la llavor a la farina. Els processos agrícoles protohistòrics a la Catalunya Occidental, Lattes: CNRS.

Barker, G. (2005). Agriculture, pastoralism, and Mediterranean landscapes in prehistory. In E. Blake \& A. B. Knapp (Eds.), The archaeology of Mediterranean prehistory (pp.46-76). Oxford: Blackwell.

Beug, H.J. (2004). Leitfaden der Pollenbestimmung für Mittleleuropa und angrenzende Gebeite. Stuttgart: Gustav Fisher Verlag.

Bintliff, J. (2000). The concepts of "site" and "offsite" archaeology in surface artefact survey. In G. Barker y D. Mattingly (Eds.), Non-Destructive Techniques applied to Landscape Archaeology. The Archaeology of Mediterranean Landscapes (pp.200-215, Oxford: Oxbow Books.

Bintliff J.L. (2011). Agricultural Revolutions. In: A. Wossink, P.M.M.G. Akkermans \& B.S. Düring (Eds.) Correlates of Complexity. Essays in Archaeology and Assyriology dedicated to D.J.W. Meijer (pp. 15-25). Leiden: Nederlands Instituut voor het Nabije Oosten.

Bintliff J.L., \& Snodgrass A. (1988a). Off-site pottery distributions: A regional and interregional perspective. Current Anthropology 29, 506-513.

Boissinot, P. (2000). A la trace des paysages agraires. L'archeologie des façons culturales en France. Études rurales, 153 - 154, 23-38.

Boissinot, P. (2001). Archéologie des vignobles antiques du sud de la Gaule. Gallia, 58, 45-68.

Bonet, H., Mata, C., \& Moreno, A. (2007). Paisaje y hábitat rural en el territorio edetano durante el Ibérico Pleno (siglos IV-III a. C.). In A. Rodríguez \& I. Pavón (Coords.), Arqueología de la tierra: paisajes rurales de la protohistoria peninsular (pp. 247-276), Cáceres: Universidad de Extremadura.

Bronk Ramsey, C. (2009). Bayesian analysis of radiocarbon dates. Radiocarbon 51(1), 337-60. Brown A. G. and Walsh K. (2017). Societal stability and environmental change: Examining the archaeology-soil erosion paradox. Geoarchaeology, 32: 23-35.

Burjachs, F., López Sáez, J.A. \& M.J. Iriarte (2003). Metodología Arqueopalinológica. In R. Buxó \& R. Piqué (eds.): La recogida de muestras en Arqueobotánica: objetivos y propuestas metodológicas. La gestión de los recursos vegetales y la transformación del paleopaisaje en el Mediterráneo occidental. Museu d'Arqueologia de Catalunya, Barcelona, 11-18.

Butzer, K. W. (2005). Environmental history in the Mediterranean world: cross-disciplinary investigation of cause-and-effect for degradation and soil erosion. Journal of Archaeological Science 32(12), 1773-1800.

Buxó, R. (1997). Arqueología de las plantas. Barcelona: Crítica.

Buxó, R. (2008). The agricultural consequences of colonial contacts on the Iberian Peninsula in the first millennium B.C. Vegetation History and Archaeobotany 17: 145-154.

Buxó, R., Principal, J., Alonso, N., Belarte, M.C., \& Colominas, L. (2010). Prácticas alimentarias en la Edad del Hierro en Cataluña. Saguntum: $N^{\circ}$ Extra 9, De la cuina a la taula. IV reunió d"economia en el primer mil·lenni ac (pp.82-99). València: Universitat de València. 
Carrión, J. S., Munuera, M., Dupré, M., \& Andrade, A. (2001). Abrupt vegetation changes in the Segura Mountains of southern Spain throughout the Holocene. Journal of Ecology, 89, 783797.

Carrión, J. S. (2002). Patterns and processes of Late Quaternary environmental change in a montane region of southwestern Europe. Quaternary Science Reviews, 21, 2047-2066.

Carter, S. P., \& Davidson, D. (1998). An evaluation of the contribution of soil micromorphology to the study of ancient arable agriculture. Geoarchaeology 13(6), 535-547.

Casarotto, A., Stek, T.D., Pelgrom J., van Otterloo, R.H., \& Sevink J. (2018). Assessing visibility and geomorphological biases in regional field surveys: The case of Roman Aesernia. Geoarchaeology 33:177-192. https://doi.org/10.1002/gea.21627

Courty, M.A., Goldberg, P., \& Macphail, R. (1989). Soils and micromorphology in Archaeology. Cambridge: Cambridge University Press.

Day, J.H. (1983). The Canadian Soil Information System (CanSIS): manual for describing soils in the field. Agriculture Canada Expert Committee on Soil Survey. Ottawa: Agriculture Canada Research Branch.

De la Cruz, J., Yanes, M., Sánchez, C.P., \& Simón, M. (2010). Ambientes semiáridos del sureste andaluz. Altiplano estepario. Sevilla: Junta de Andalucía.

Díaz-Fierros, F., \& Gil Sotres, F. (1984). Capacidad productiva de los suelos de Galicia. Mapa 1:200.000. Santiago de Compostela: Universidade de Santiago de Compostela.

Chalk, P.M. (1998). Dynamics of biologically fixed $N$ in legume-cereal rotations: A review. Australian Journal of Agricultural Research 49, 303-316.

Chapa, T., \& Mayoral, V. (2007). Arqueología del trabajo: el ciclo de la vida en un poblado ibérico, Madrid: Akal.

Echevarría Sánchez, A., \& Vera-Rodríguez, J.C. (2015). "“Los inicios de la viticultura en la Península Ibérica a partir de las huellas de cultivo"', Francia Verde, R., (coord.), Historia y arqueología en la cultura del vino (pp.57-68). Logroño: Instituto de Estudios Riojanos.

Ejarque A., \& Orengo H. A. (2009) "Legacies of Change: the shaping of cultural landscapes in a marginal Mediterranean mountain range, the Garraf Massif, North-Eastern Spain", Oxford Journal of Archaeology 28(4), 425-440.

Fall, P. L.; Falconer, Steven E.; Galletti, Ch.S.; Shirmang, T.; Ridder, E. \& Klinge, J. (2012). Long-term agrarian landscapes in the Troodos foothills, Cyprus. Journal of Archaeological Science 39 (7), 2335-2347.

Ferro-Vázquez, C., Martinez-Cortizas, A., Novoa-Munoz, J. C., Ballesteros-Arias, P. \& CriadoBoado, F. (2014). 1500 years of soil use reconstructed from the chemical properties of a terraced soil sequence. Quaternary International 346, 28-40.

Foley, R. (1981). Off-site archaeology and human adaptation in Eastern Africa: an analysis of regional artifact density in the Amboseli, Southern Kenya. Oxford: British Archaeological Reports.

Fort, R., Chapa, T., \& González, S. (2017) "Selective use of limestone in Iberian Iron Age sculptures and monuments: a case study from Jutia (Albacete, Spain)", Archaeological and Anthropological Sciences, 1-18. https://doi.org/10.1007/s12520-017-0574-6

Frederick, C., \& A. Krahtopoulou. (2008). The Stratigraphic Implications of Long-term Terrace Agriculture in Dynamic Landscapes: Polycyclic Terracing from Kythera Island, Greece. Geoarchaeology 23, 550-585.

Gener, M.; Romero, D.; González, S.; García, J. (2016): Estudio metalúrgico de las armas ibéricas halladas en el valle de Jutia (Nerpio-Yeste, Albacete). Trabajo, armamento, ritual y comunidades de montaña. Gladius, 36, 7-31, doi: 10.3989/gladius.2016.0001

Gilet-Blein N., Marien G., \& Evin J. (1980). Unreliability of ${ }^{14} \mathrm{C}$ Dates from Organic Matter of Soils. Radiocarbon 22(3), 919-929.

Gilman, A. (2013). Were there states during the later Prehistory of Southern Iberia?. In M.C. Berrocal, L. García Sanjuán \& A. Gilman (eds.), The prehistory of Iberia: debating early social stratification and the State (pp. 10-28). Londres-Nueva York: Routledge. 
Goeury, C., \& de Beaulieu, J.L. (1979). À propos de la concentration du pollen à l'aide de la liqueur de Thoulet dans les sédiments minéraux. Pollen Spores 21, 239-251.

Gorenflo, L. J. \& Gale, N. (1990). "Mapping regional settlement in information space". Journal of Anthropological Archaeology, 9, 240-274.

Goy, J.L., Zazo, C., Rodriguez-Vidal, J.: “Cordilleras Béticas-Islas Baleares”, In M. Gutiérrez Elorza (ed. coord.): Geomorfología de España. Madrid, 1994, 123-157.

Grimm, E.D. (2004). TGView. Illinois State Museum, Research and Collection Center, Springfield.

Grau, I. (2014). The Iron Age landscape of Alcoi Valley, eastern Iberia: Agricultural intensification and sociopolitical dynamics. Journal of Field Archaeology 39(2), 124-133.

Grau, I. (2016): Archaeological surveys in areas with a high density of artefacts: Analysis and interpretation proposals. Quaternary International, vol. 435, Part B, 12 April 2017, Pages 7180doi:10.1016/j.quaint.2015.12.063Halstead, P. (1987). Traditional and ancient rural economy in Mediterranean Europe: plus ça change?. The Journal of Hellenic Studies 107, 77-87.

Hammer, E. (2014). Local landscape organization of mobile pastoralists in southeastern Turkey. Journal of Anthropological Archaeology 35: 269-288.

Hather, J. G. (2000). The identification of the Northern European woods. A guide for archaeologists and conservators. Londres: Archetype Publications.

Hidalgo, R., \& Fernández, I. (1996). Contribución al estudio morfológico del polen de plantas hortícolas cultivadas en Andalucía. Lagascalia 18, 151-162.

Holliday VT. (2004). Soils in Archaeological Research. Oxford: Oxford University Press.

Horden, P., \& Purcell, N. (2000). The corrupting sea. A study of Mediterranean history. Oxford: Blackwell.

IGME 1979. Mapa Geológico de España 1:50.000. Yetas de Abajo (23-35). Madrid: Ministerio de Industría y Energía.

ISO 10693 (1995). Soil quality-Determination of carbonate content-Volumetric method.

ISO 11732 (2005). Water quality-Determination of ammonium nitrogen-Method by flow analysis (CFA and FIA) and spectrometric detection.

Jérez Mir, L. (1984), "Unidades geológicas representadas en Albacete en su relación con el relieve provincial", Panadero, M. (dir.), II Seminario de Geografía de Albacete (pp. 23-59). Instituto de Estudios Albacetenses-CSIC: Albacete.

López Bellido, L. (2009). Abonado de los cereales de invierno: trigo y cebada. In Guía práctica de la fertilización racional de los cultivos en España (pp.123-133). Madrid: Ministerio de Medio Ambiente y Medio Rural y Marino.

López-Sáez, J.A., López-García, P. \& Burjachs, F. (2003). Arqueopalinología: Síntesis crítica. Pollen 12, 5-35.

López-Sáez, J.A., \& López-Merino, L. (2005). Precisiones metodológicas acerca de los indicios paleopalinológicos de agricultura en la Prehistoria de la Península Ibérica. Portugalia 26, 53-64. López Sáez, J.A.. López Merino, L., Pérez Díaz, S., Parcero-Oubiña, C., \& Criado-Boado, F., (2009). Contribución a la caracterización de los espacios agrarios castreños: documentación y análisis palinológico de una posible terraza de cultivo en el castro de Follente (Caldas de Reis, Pontevedra). Trabajos de Prehistoria 66(2), 171-182.

López-Sáez, J.A., Sánchez-Mata, D., Alba-Sánchez, F., Abel-Schaad, D., Gavilán, R.G. \& Pérez-Díaz, S., (2013). Discrimination of Scots pine forests in the lberian Central System (Pinus sylvestris var. iberica) by means of pollen analysis. Phytosociological considerations. Lazaroa 34, 191-208.

López-Sáez, J.A., Abel-Schaad, D., Pérez-Díaz, S., Blanco-González, A., Alba-Sánchez, F., Dorado, M., Ruiz-Zapata, B., Gil-García, M.J., Gómez, C. \& Franco-Múgica, F. (2014). Vegetation history, climate and human impact in the Spanish Central System over the last 9,000 years. Quaternary International 353, 98-122.

Mata, C., \& Bonet, H. (1993). "La cerámica ibérica: Ensayo de tipología”. En VV. AA.: Estudios de arqueología ibérica y romana (pp. 117-173). Valencia: SIP. 
Mata, C.; Moreno, A.; Pérez Jordà, G.; Quixal, D. \& Vives-Ferrándiz, J. (2009). Casas y cosas del campo: hábitat agrícola y estructura social en los territorios de Edeta y Kelin (siglos V-III a.n.E), ArqueoMediterrània 11, 143-152.

Mayoral, V., Chapa, T.; Uriarte, A.; Cabrera, A. (2006) "'Escuchando el ruido de fondo: estrategias para el estudio de los paisajes agrarios tardoibéricos en la región del Guadiana Menor"'. In A. Orejas (Ed.) Arqueología espacial: espacios agrarios (pp.87-114), Teruel: Seminario de Arqueología y Etnología turolense.

MMA; 2002. Plan Forestal Español. Madrid: Ministerio de Medio Ambiente.

Moore, P.D., Webb, J.A., \& Collinson, M.E. (1991). Pollen analysis. London: Blackwell.

Mortvedt, J.J., Murphy, L.S., \& Follet, R.H. (1999). Fertilizer technology and application. Willoughby: Meister Publishing.

Mujika Alustiza, J.A.; Agirre García, J.; Edeso Fito, J.M.; Lopetegi Galarraga, A.; Pérez-Díaz, S. \& Ruiz Alonso, M. (2013). La continuidad de la actividad pastoril durante la época romana en la zona de Argarbi, Kobie 32, 217-258.

Nadal Moyano, S., Moreno Yangüela, M.T., \& Cubero Salmerón, J.I. (2004). Las leguminosas en grano en la agricultura moderna. Madrid: Mundi-Prensa.

Nicosia, C.; Langohr, R.; Carmona, P.; Gómez Bellard, C.; Modrall, E.; Ruíz, J. M. \& Van Dommelen, P. (2013). Land Use History and Site Formation Processes at the Punic Site of Pauli Stincus in West Central Sardinia. Geoarchaeology 28(4): 373-393.

Pérez Cutillas, P., Cataldo, M.F., Dema, M.A, de Vente \& Boix-Fayos, J. (2016). "'Análisis de la respuesta hidrológica en una cuenca de media montaña mediterránea afectada por procesos de recuperación de la cubierta vegetal'"'. In R. García, F. Alonso, F. Belmonte, D. Moreno (coords.), XV Coloquio Ibérico de Geografía, Murcia: Asociación de Geógrafos Españoles.

Pérez Jordà, G., Iborra, M.P., Grau, E., Bonet, H., \& Mata, C. (2000). La explotación agraria del territorio en época ibérica: Los casos de Edeta y Kelin. In R. Buxó \& E. Pons. Els productes alimentaris d'origen vegetal a l'Edat del Ferro de l'Europa occidental: de la producció al consum (pp. 151-167). Barcelona: Museu d"Arqueologia de Catalunya.

Pérez Jordà G., (2013). La agricultura en el País Valenciano entre el VI y el I milenio a.C. València: Universitat de València.

Puy A., \& Balbo A. L. (2013). The genesis of irrigated terraces in al-Andalus. A geoarchaeological perspective on intensive agriculture in semi-arid environments (Ricote, Murcia, Spain). Journal of Arid Environments 89: 45-56.

Puy, A., Balbo, A.L., \& Bubenzer, O. (2016). Radiocarbon dating of agrarian terraces by means of buried soils. Radiocarbon, vol. 58 (02), 345-363.

Reimer P.J., Bard E., Bayliss A., Beck J.W., Blackwell P.G., Bronk C., Caitlin R., Hai E.B., Edwards R.L., Friedrich M., Grootes P.M., Guilderson T.P., Haflidason H., Hajdas I., Hatté C., Heaton T., Hoffmann D.L., Hogg A.G., Hughen K.A., Kaiser K.F., Kromer B., Manning S.W., Niu M., Reimer R.W., Richards D.A., Marian Scott E., Southon J.R., Staff R.A., Turney C.S.M., \& van der Plicht J. (2013). IntCal13 and Marine13 radiocarbon age calibration curves 0-50,000 years cal BP. Radiocarbon 55(4), 1869-87.

Reille, M. (1999). Pollen et spores d'Europe et d'Afrique $d u$ Nord, $2^{\text {nd }}$ edn. Marseille: Laboratoire de Botanique Historique et Palynologie.

Rendu, C., Passarrius, O., Calastrenc, C., Julia, R., Llubes, M., Illes, P., Campmajo, P., Jodry, C., Crabol, D., Bille, E., Conesa, M., Bousquet, D., \& Lallemand, V. (2015). Reconstructing past terrace fields in the Pyrenees: Insights into land management and settlement from the Bronze Age to the Early Modern era at Vilalta. Journal of Field Archaeology 40 (4), 461-480.

Rodríguez, A.; Chautón, H., \& Duque, D. (2006). Paisajes rurales protohistóricos en el Guadiana Medio: Los Caños (Zafra, Badajoz). Revista portuguesa de arqueología, 9.1, 71-114.

Ruiz, A., \& Molinos, M. (1993). Los iberos. Análisis arqueológico de un proceso histórico. Barcelona: Crítica.

Ruiz, A., Serrano, J. L., Molinos, M., \& Rodríguez, M. O. (2007). La tierra y los Iberos en el Alto Guadalquivir. In A. Rodríguez e I. Pavón (coords.): Arqueología de la tierra. Paisajes rurales de la protohistoria peninsular (pp.225-245), Cáceres: Universidad de Extremadura. 
Sánchez, A., \& Cañavate, Mª L. (1998). Indicadores químicos para la arqueología. Jaén, Jaén: Universidad de Jaén.

Sánchez, J.A., Bravo, E. and Madaria, J.L. (2015). Historia de la Vía Augusta en la Foia de Manuel (La Font de la Figuera, Valencia). De asentamiento prehistórico a calzada imperial romana. Adif. Valencia.

Sánchez-Palencia, F. J., Romero, D., \& Beltrán, A. (2012). Paisajes mineros en el noreste de Lusitania y Asturia meridional. In M. Zarzalejos, P. Hevia \& L. Mansilla (Eds.). Paisajes mineros antiguos en la Península Ibérica (pp.155-170). Madrid: UNED.

Sánchez-Palencia, F. J. (2014). La minería romana de la Sierra de la Peña de Francia: Las zonas arqueológicas de Las Cavenes de El Cabaco y El Pinalejo-Tenebrilla (Salamanca). In F.J. Sánchez-Palencia (Ed.) Minería en zonas interfronterizas de Castilla y León y Portugal (pp.135-180), Valladolid: Junta de Castilla y León.

Sánchez-Palencia, F. J., Beltrán, A., Pecharromán, J.L., Romero, D., \& Currás, B. (2014). La minería romana de Pino del Oro y su entorno inmediato (Salamanca). In Sánchez-Palencia, F.J. (ed) Minería en zonas interfronterizas de Castilla y León y Portugal (pp.181-216), Valladolid: Junta de Castilla y León.

Schweingruber, F.H. (1990). Microscopic Wood Anatomy. Swiss Federal Institute for Forest, Snow and Landscape Research.

Serrano-Peña, José-Luis. (2015). Iberos y Romanos en Jaén. Formas de interrelación política, económica y cultural. Una lectura desde el territorio de Aurgi. [http://hdl.handle.net/10953/654]

Serrano Peña, J.L.; Portero Fernández, V., \& Cano Carrillo, J. (2011). Historia de un arroyo: de marroquíes bajos al centro comercial El Corte Inglés de Jaén, Granada.

Singh, A.K., Bharati, R.C., Manibhushan, N.C., \& Pedpati, A. (2013). An assessment of faba bean (Vicia faba L.) current status and future prospect. African Journal of Agricultural Research 8, 6634-6641.

Tallón-Armada, R., Costa-Casais, M., Schellekens, J., Taboada Rodríguez, T., Vives-Ferrándiz Sánchez, J., Ferrer García, C., Abel Schaad, D., López-Sáez, J.A., Carrión Marco, Y., \& Martínez Cortizas, A. (2014). Holocene environmental change in Eastern Spain reconstructed through the multiproxy study of a pedo-sedimentary sequence from Les Alcusses (Valencia, Spain). Journal of Archaeological Science, 47, 22-38.

Tartaron, T. F., Gregory, T. E., Pullen, D. J., Noller, J. S., Rothans, R. M., Rife, J. L., Tzortzopoulon-Gregory, L., Schon, R., Caraher, W. R., Pettegrew, D. K., \& Nakassis, D., (2006). The Eastern Korinthia Archaeological Survey. Hesperia 75(4): 453-523.

Trueba, E., Millán, R., Schmid, T., Lago, E., Roquero, E., Magister, M. (1995). Base de Datos de propiedades edafológicas de los suelos españoles. vol. IX, Castilla-La Mancha, Madrid: Ciemat.

Van Geel, B. (2001). Non-pollen palynomorphs. In: Smol, J.P., Birks, H.J.B., \& Last, W.M. (Eds.), Tracking environmental change using lake sediments, vol. 3, Terrestrial, algal, and siliceous indicators, (p.99-119). Dordrecht: Kluwer.

Vernet, J. L., Ogereau, P., Figueiral, I., Machado, C., \& Uzquiano, C. (2001). Guide d'identification des charbons de bois préhistoriques et récents. Sud-Ouest de l'Europe: France, Péninsule Ibérique et Îles Canaries. Paris: CNRS.

Vita-Finzi, C., \& Higgs, E.S. (1970). Prehistoric Economy in the Mount Carmel Area of Palestine: Site Catchment Analysis. Proceedings of the Prehistoric Society 36, 1-37.

Wilkinson, T. J. (1982). The Definition of Ancient Manured Zones by Means of Extensive SherdSampling Techniques. Journal of Field Archaeology 9(3), 323-333.

White, K. D. (1970). Roman farming. New York: Cornell University Press.

WRB 2007: World Reference base for Soil Resources 2007, first update. World Soil Resources Reports, $n^{\circ} 103$, Rome, FAO.

Zhang M., Li C., Li Y.C., \& Harris W.G. (2014). Phosphate minerals and solubility in native and agricultural calcareous soils. Geoderma 232-234, 164-171. 


\section{Footnotes}

Footnote 1: These flights are partially accessible online (http://centrodedescargas.cnig.es), although the stereo-pair has to be obtained by contacting the Spanish Army (Centro Cartográfico y Fotográfico del Ejército del Aire, CECAF).

\section{Figure captions}

Fig. 1: Location of the Jutia valley in Albacete, southeastern Iberian Peninsula

Fig. 2: Jutia Valley geomorphology. Based on: Mapa Geomorfológico 1:50.000. IGME. Hoja 866 (23-34), Yeste. Madrid, 1999-2001; Goy, Zazo, \& Rodriguez-Vidal, 1994, 123-157; Fort, Chapa, \& González, 2017, fig. 2)

Fig. 3: Jutia valley. Location of the sectors and trenches mentioned in the text

Fig. 4: Photointerpretation, potential uses and isochronous map of the Jutia valley. Computer modeled isochronous map (equidistance=15 min) from Jutia-El Álamo settlement

Fig. 5: Aerial photograph and kernel interpolation-based concentration of archaeological materials at Cerro de Jutia (left) and Jutia-El Álamo (right) (distance between contours $=5 \mathrm{~m}$ )

Fig. 6_1: Geophysical survey in Sector 5. Plan view and cross-section showing change in slope suggesting the existence of terraces

Fig. 6_2: Geophysical survey in Sector 5. Plan view, topographic and cross-section showing change in slope suggesting the existence of terraces

Fig. 7: Map of material scatter documented in the archaeological survey of "Jutia-El Álamo": (top) Iberian age material scatter; (center) Roman Age material scatter; (bottom) density map plotted with ArcGis Kernel software (distance between contours $=5 \mathrm{~m}$ )

Fig. 8: Soil profiles and radiocarbon ages at trenches T2 and T1 (Jutia, Sector 5)

Fig. 9: Pollen diagram for Sector 5, T2

Fig. 10: Soil profiles and radiocarbon ages at trenches T6 and T7 (Jutia, Sector 4)

Fig. 11: Pollen diagram for Sector 4, T6

Table captions

Table 1: Field descriptions of sequences at Jutia

Table 2: Radiocarbon dates, Jutia Valley

Table 3: Physical-chemical characterization of soils

\section{Supplementary material}

Supplementary material for review 1: Location of the Jutia valley in Albacete, southeastern Iberian Peninsula

Supplementary material for review 2: Jutia Valley geomorphology. Based on: Mapa Geomorfológico 1:50.000. IGME. Hoja 866 (23-34), Yeste. Madrid, 1999-2001; Goy, Zazo, \& Rodriguez-Vidal, 1994, 123157; Fort, Chapa, \& González, 2017, fig. 2)

Supplementary material for review 3: Jutia valley. Location of the sectors and trenches mentioned in the text

Supplementary material for review 4: Photointerpretation, potential uses and isochronous map of the Jutia valley. Computer modeled isochronous map (equidistance=15 min) from Jutia-El Álamo settlement Supplementary material for review 5: Aerial photograph and kernel interpolation-based concentration of archaeological materials at Cerro de Jutia (left) and Jutia-El Álamo (right) (distance between contours $=5 \mathrm{~m}$ )

Supplementary material for review 6_1: Geophysical survey in Sector 5. Plan view and cross-section showing change in slope suggesting the existence of terraces

Supplementary material for review 6_2: Geophysical survey in Sector 5. Plan view, topographic and crosssection showing change in slope suggesting the existence of terraces

Supplementary material for review 7: Map of material scatter documented in the archaeological survey of "Jutia-El Álamo": (top) Iberian age material scatter; (center) Roman Age material scatter; (bottom) density map plotted with ArcGis Kernel software (distance between contours $=5 \mathrm{~m}$ )

Supplementary material for review 8: Soil profiles and radiocarbon ages at trenches T2 and T1 (Jutia, Sector 5)

Supplementary material for review 10: Soil profiles and radiocarbon ages at trenches T6 and T7 (Jutia, Sector 4)

Supplementary Table 1: Identification of antracological remains in agrarian areas at Jutia (T6, Sector 4 and T2, Sector 5) 

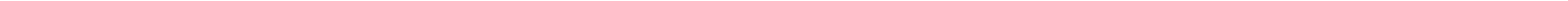


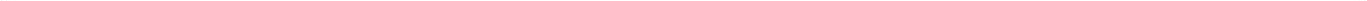




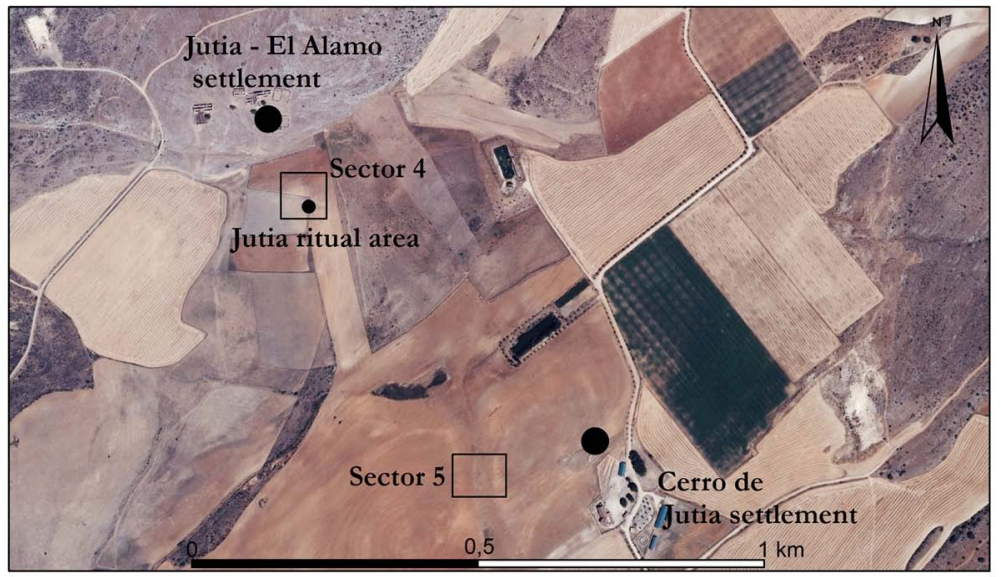

Sector 5

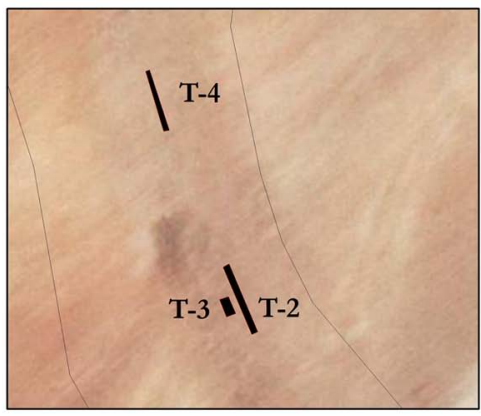

Sector 4

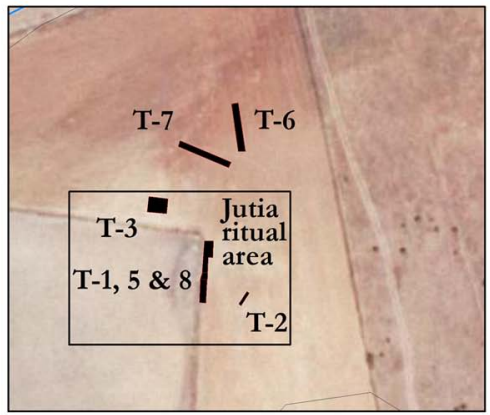

$75 \quad 100 \mathrm{~m}$ 


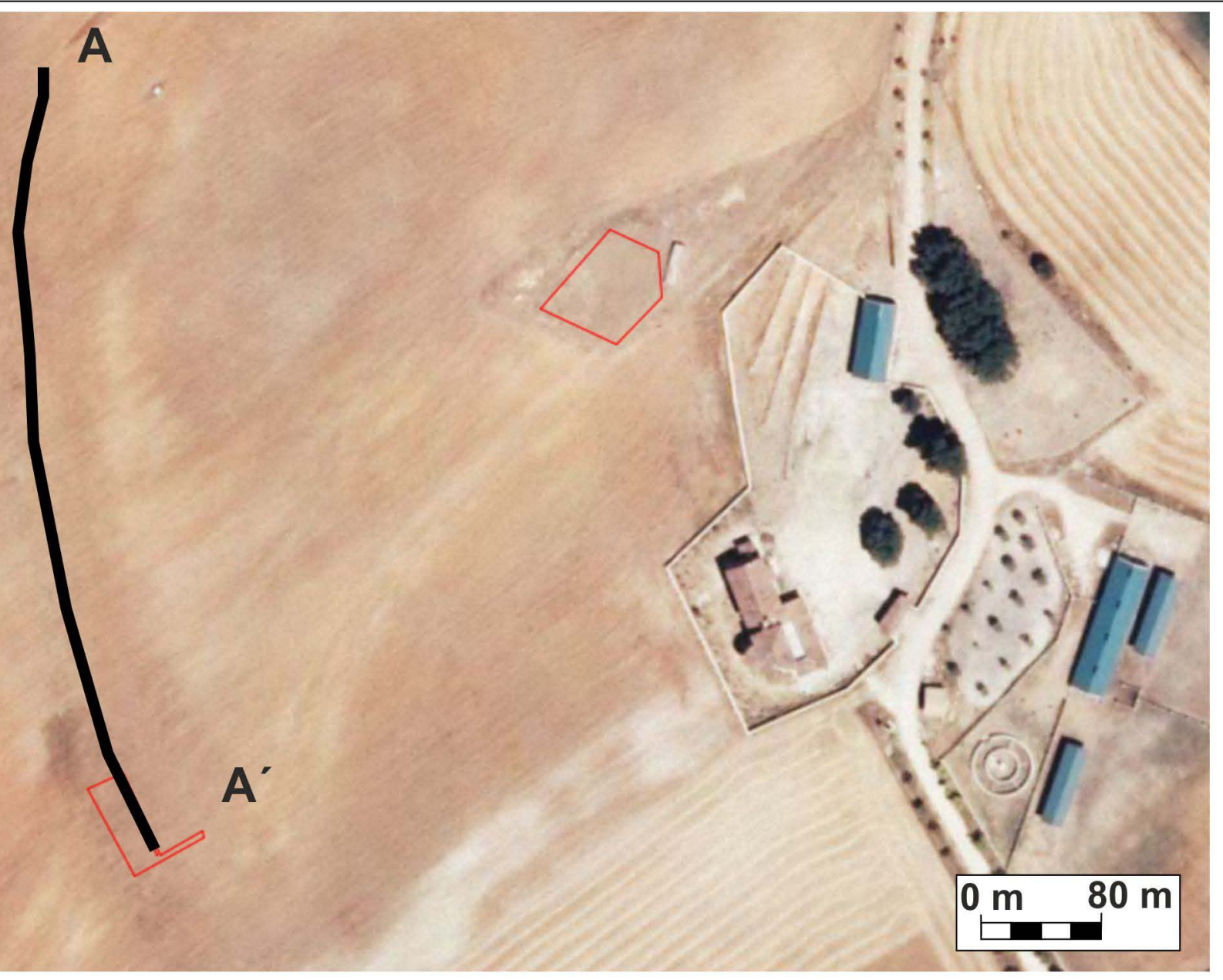

A

$A^{\prime}$

0. IboxcariT1020001

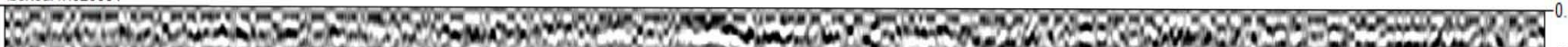

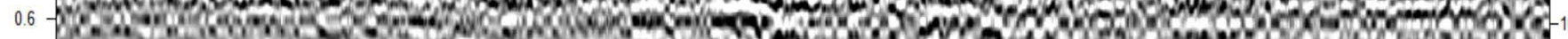
E 1.2 \begin{tabular}{llllllllllllll|l|l|l|l|l|l|l}
551680 & 551679 & 551676 & 551674 & 551673 & 551673 & 551675 & 551676 & 551677 & 551678 & 551678 & 551682 & 551683 & 551685 & 551688 & 551692 & 551695 & 551699 \\
4226867 & 4226859 & 4226847 & 4226833 & 4226819 & 4226807 & 4226796 & 4226784 & 4226772 & 4226759 & 4226746 & 4226734 & 4226723 & 4226717 & 4226705 & 4226693 & 4226681 & 4226670 \\
0 & 8 & 30 & 43 & 57 & 70 & 82 & 94 & 117 & 136 & 157 & 172 & 185 & 194 & 212 & 231 & 243 & 255
\end{tabular} - IboxcarlT1020001

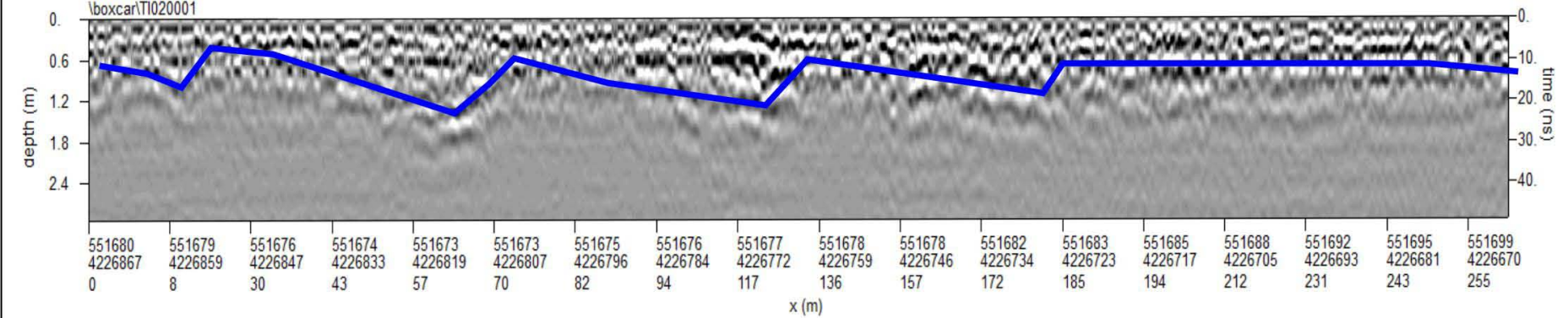



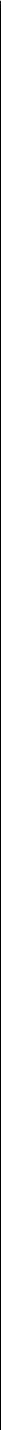

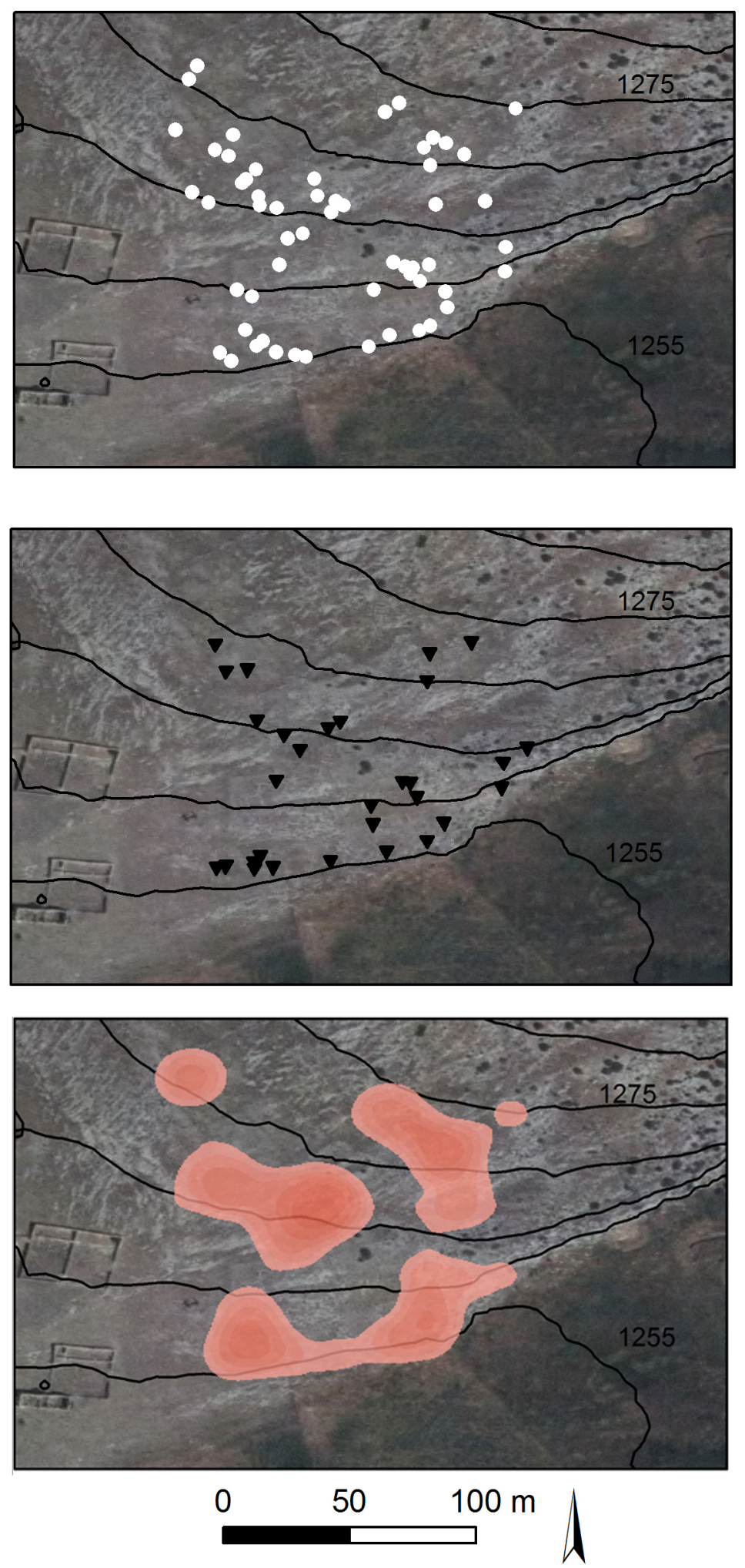


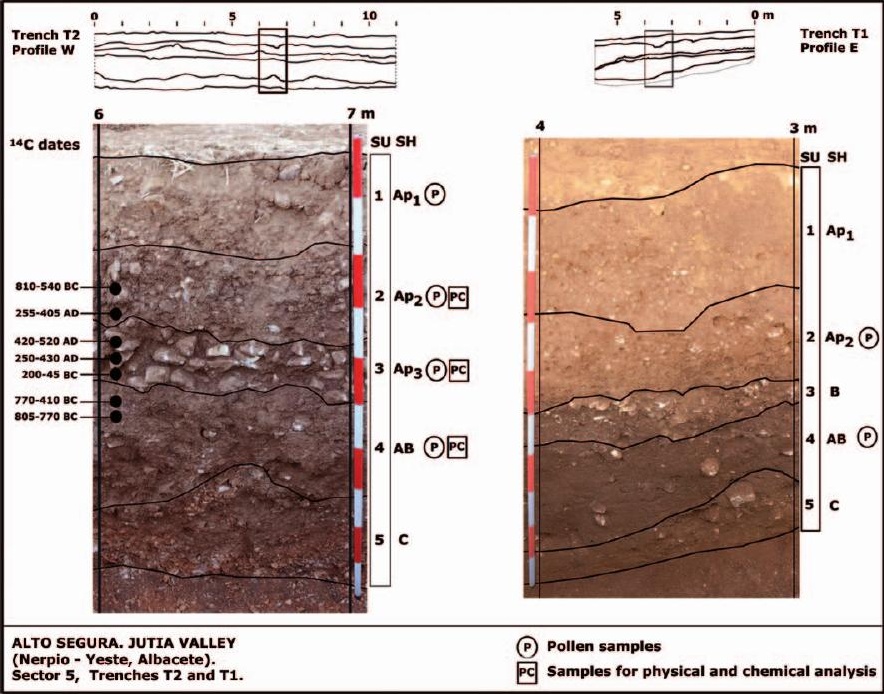




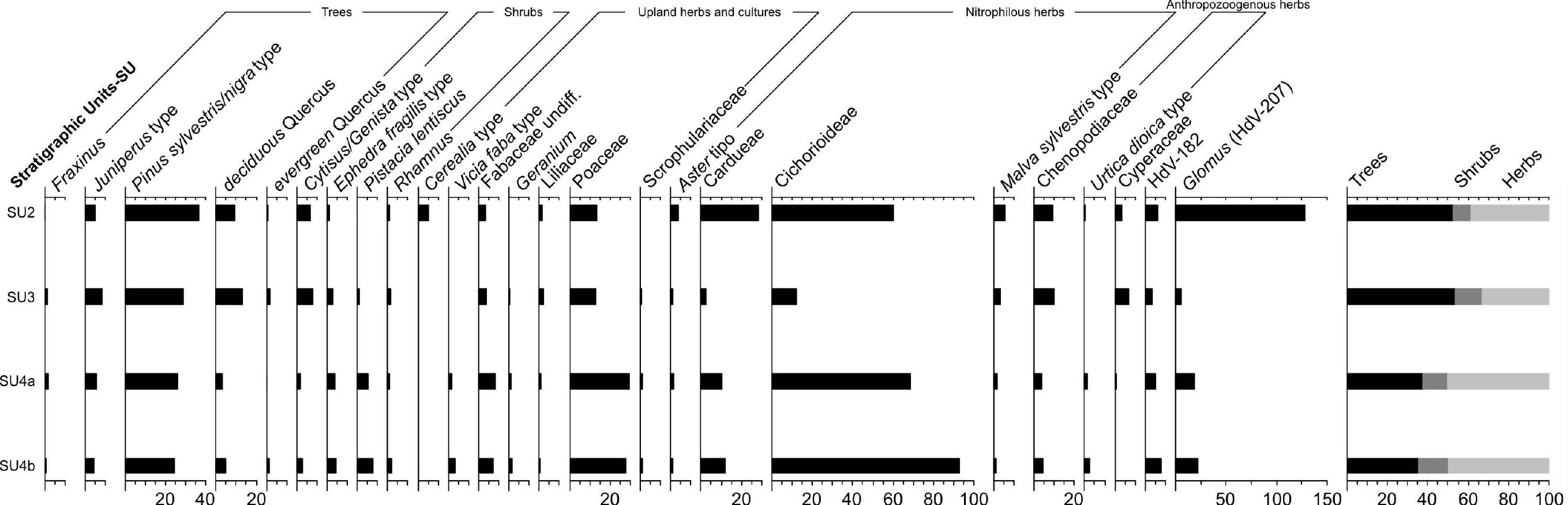


Trench T6

Profile E
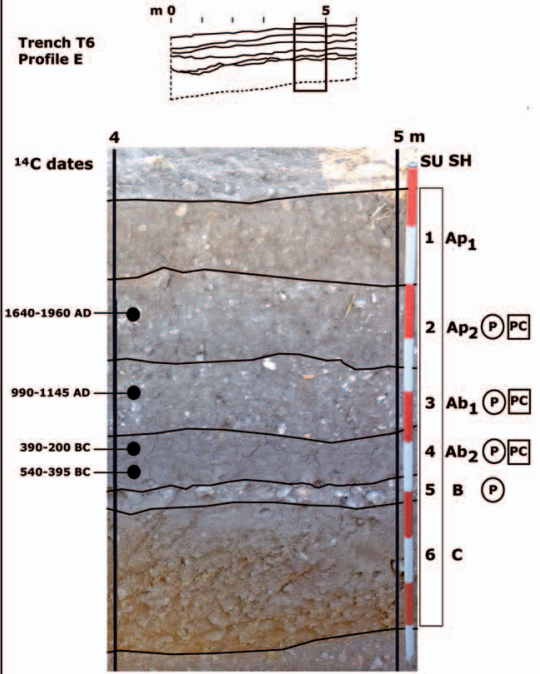

ALTO SEGURA. JUTIA VALLEY

(Nerpio - Yeste, Albacete).

Sector 4, Trenches T6 and T7.
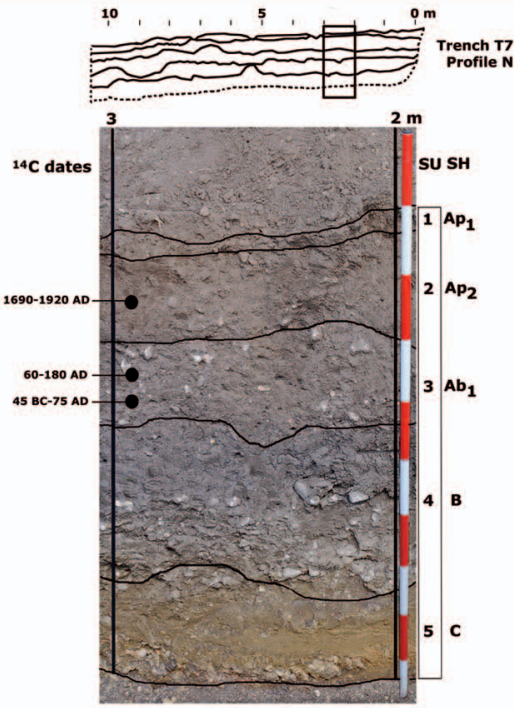

(P) Pollen samples

PC Samples for physical and chemical analysis 
